\title{
Biblical Chronology and the Transmission of the Theory of Six "World Ages" to China: Gezhi aoliue 格致奧略 (Outline of the mystery [revealed through] natural science; before 1723)
}

\begin{abstract}
Ad Dudink
[Ad Dudink (1947) is a researcher at the University of Leuven (KUL). He studied theology (especially history of religions in China) and sinology in Amsterdam and Leiden. In 1995 he received his Ph.D. from Leiden University (supervisor: Erik Zürcher). Since 1996 he has collaborated in Leuven with Nicolas Standaert in projects related to the history of Christianity in seventeenth- and eighteenthcentury China, e.g. the Chinese Christian Texts database, and publishing collections (1996, 2002, 2009, 2013, in all 77 volumes) of facsimile editions of such texts.Contact:Ad.Dudink@gep.kuleuven.be]
\end{abstract}

\begin{abstract}
This article is primarily concerned with the question of what kind of text Gezhi aolüe 格致奧略 (Outline of the mystery [revealed through] natural science), a unique ms. copy (1820) from the Zikawei Library in Shanghai and published for the first time in 1996, precisely is. Gezhi aolüe appears to be older than 1820 (dating to before 1723), and to be a summary of one of the "Manila incunabula" (as Van der Loon called them), viz. Gewu qiongli bianlan 格物穹理便覽 (Handy compendium for investigating things and extending knowledge, 1607) composed by the Dominican friar Tomás Mayor for the Minnan-speaking Chinese in Manila, which in turn is based on Luis de Granada's Introducción del Símbolo de la Fe (1583). The article further concentrates on the biblical chronology (Vulgata) embedded in a scheme of six "world ages" (from Adam, Noah, Abraham, Moses, Salomo, and Zerubbabel to Christ) that Gewu qiongli bianlan presents (a chronology not found in the Introducción). Due to the absence, at that time, of a Chinese translation of the Bible and especially of the Old Testament, Gezhi aolüe (as well as the ms. Renlei yuanliu 人類源流 (The origin of mankind) that seems to be based on Mayor's text too) that was not compiled by Western missionaries reproduces for quite a number of less well-known names in the genealogy from Adam to Christ the Minnan or Hokkien 'transliterations' used in Gewu qiongli bianlan. The article concludes with two appen-
\end{abstract}


dices: 1) a survey of which biblical chronology Chinese Christian texts of the seventeenth and eighteenth centuries use: the Vulgata chronology (the world was created some 4000 years before Christ), or the Septuagint chronology (the world was created some 5200 years before Christ); and 2) a reproduction of the genealogy of Christ (in Chinese and, of course, not using Minnan transliterations) that Carlo di Orazio da Castorano, a Franciscan missionary in Shandong, had printed in 1704 (the only known copy is preserved in the Vatican Library, see frontispiece and attached illustration of this issue of EASTM).

That the chronologies of Aztec, Chinese and Egyptian histories had a great impact on the scholarly world of early modern Europe is well known. ${ }^{1}$ They challenged chronologies derived from the Latin translation (mainly done by Hieronymus around $400 \mathrm{CE}$ ) of the Hebrew Old Testament, a translation called Vulgata and declared to be 'authentic' by the Council of Trent in 1546. According to Vulgata-derived chronologies, the Creation took place some 3950 years BCE, and the Flood some 2300 years BCE. In the early days of Christianity, however, another chronology had been prevalent, that of the Septuagint, a Greek translation of the Hebrew Old Testament made in Alexandria (Egypt) for the Greek-speaking Jewish community there in the third and second centuries BCE. It has a rather different chronology in the Book of Genesis (translated ca. 250 BCE). ${ }^{2}$ Several Patriarchs are made 100 years older when they begat their first or succeeding son, e.g. Adam is said to have been 230 years old when he begat Seth, and not 130 as in the Hebrew text and in the Vulgata translation. There is even a new patriarch inserted before Salech (great-grandson of Noah), the so-called second Cainan (Cainan II), who begat Salech when he was 130 years. Thus, in this version, the Creation took place some 1250 years and

\footnotetext{
${ }^{1}$ Cf. Grafton 2004, p. 172; 2006, pp. 67-69; see also Witek 1983.

${ }^{2}$ Cf. Jobes \& Silva 2000, p. 29: "The term Septuagint, which has been used in a confusing variety of ways, gives the inaccurate impression that this document is a homogenous unit. Important distinctions sometimes need to be made, such as the contrast between the initial translation of the Pentateuch (the Septuagint proper) and the earliest translations of other books (the Old Greek). [...] The Pentateuch was originally translated in Alexandria around the year 250 B.C.E. and the rest of the Hebrew Bible was translated within the following two centuries" (see also pp. 19-20 of Tilly 2005). Pentateuch is the Greek name of the Torah or the Five Books of Moses (Genesis-Deuteronomy).
} 
the Flood some 660 years (in 2957 BCE) earlier, ${ }^{3}$ which now preceded the first dynasty of Egypt. The scholars at Alexandria who translated Genesis apparently accommodated the chronology of this book to the official Egyptian chronology recorded by Manetho in his Greek history of Egypt (Aegyptiaca, first half of third century $\mathrm{BCE}$ ), with its list of dated reigns of the Pharaohs. ${ }^{4}$

In the seventeenth century, scholars preferred this Septuagint chronology when confronted with the histories of kingdoms and empires outside of Europe, including China. In order to accommodate ancient Chinese history, "the acceptance of a Septuagint-derived chronology became increasingly common among those who wrote about China during the century and a half after Vossius [Dissertatio de vera aetate mundi, 1659]. Jesuit missionaries not only used it in China, but after 1658 [Martini, Sinicae historiae] most of them used it for accounts published in Europe as well." ${ }^{5}$ Less well known is that during the seventeenth and eighteenth centuries, missionaries transmitted to China not only Septuagint-derived but also Vulgata-derived chronologies, although the latter on a much more restricted scale. In general,

${ }^{3} 2957$ (viz. 5199-2242) versus 2296 (viz. 3952-1656); cf. Von den Brincken 2000, p. 91 (according to the most influential scheme of five world-ages, that of Saint Augustin):

$\begin{array}{llrr}\text { aetas 1, } & \text { Adam-Noah } & 2242 & 1656 \\ \text { aetas 2, } & \text { Noah-Abraham } & 942 & 292 \\ \text { aetas 3, } & \text { Abraham-David } & 941 & 942 \\ \text { aetas 4, } & \text { David-exile } & 485 & 473 \\ \text { aetas 5, } & \text { exile-Christ } & 589 & 589 \\ \text { total } & & 5199 & 3952\end{array}$

Notice, however, that 'the' Vulgata or Septuagint chronology does not exist; it would be better (which I will not do all the time) to speak of Vulgata- or Septuagintderived chronologies. For example, Conradus Lycostenes in the chapter "Diversitas supputationum, ab Adamo vel condito potius mundo, usque ad Christi salvatoris gloriosam nativitatem, ex diversis chronographis" of his Prodigiorum ac ostentorum chronicon (Basilea, 1577) gives a list of 34 totals for the duration of the period Creation-Incarnation, from 3707 to 6984 years; 15 of them vary between 3952 and 3962 years, and 13 of them between 5029 and 5801 years (not included Alphonsus Rex: 6984): 5029, 5049, 5195 (twice: Philo and Augustinus), 5196, 5199 (Eusebius of Caesarea), 5201 (twice), 5328, 5353, 5500, 5600, 5801; see table on p. 106 of María José Vega Ramos 1994. See also Mangenot 1912, col. 720. Still a well-known Vulgata chronology is that of James Ussher (1581-1656), who in his Annales veteris testamenti (1650) put the Creation in 4004 BCE (cf. Barr 1985).

${ }^{4}$ See Larsson 1983, p. 403. For Manetho, see also Grafton 2006, pp. 78-79.

${ }^{5}$ Van Kley 1971, p. 370. For Martini, see also Grafton 2006, pp. 80-81. 
the chronologies they transmitted were not very detailed: we only hear of the age of the world, or how many years had elapsed from the Creation to the Incarnation of Christ, sometimes with the Flood or the time of Moses as an intermediate stage. ${ }^{6}$ In the present article, I concentrate on one detailed Vulgata chronology (within a scheme of six "world ages") presented in the broader context of narrating some main events of biblical history (before the birth of Christ). This Vulgata chronology is found in two or three thus far hardly known texts (possibly all never printed), transmitted in China by Chinese converts from a book published in 1607 by a Dominican missionary for Chinese in Manila. The historical significance of these texts is probably limited, but they confirm that one should be careful in suggesting that the Catholic missions in China during the seventeenth and eighteenth centuries merely used Septuagint-derived chronologies.

\title{
1. Vulgata and Septuagint chronologies both transmitted to China: the reactions of Mei Wending 梅文鼎 (1633-1721) and Antoine Gaubil SJ (1689-1759)
}

Although there was a preference for the Septuagint chronology, it was, like in Europe, not universally accepted. There simply was no uniform biblical chronology, and the difference between Vulgata and Septuagint chronologies could not but be transmitted to China. Antoine Gaubil's complaint (probably in 1733, see below) is understandable but unrealistic at the same time. In a letter of 23 October 1731 he writes from Beijing:

\begin{abstract}
The two Regulos were already informed about the differrence of calculation between the Vulgata and the Septuagint. More than twenty years ago, a clever Chinese called Mey had printed an otherwise good book in which this difference is reported in detail. ${ }^{7}$
\end{abstract}

The Mey concerned is, not surprisingly, Mei Wending 梅文鼎 (1633-1721) who indeed reports in detail (without mentioning 'Vulgata' and 'Septuagint') about the differences in the calculation of the age of the world in Chinese

\footnotetext{
${ }^{6}$ See Appendix 1: "Survey of Chinese-Christian texts (seventeenth to eighteenth century): Vulgata or Septuagint chronology".

7 "Les 2 Regulos étoient déjà instruits de la différence des calculs de la Vulgate et des 70. Un Chinois habile appelé Mey fit imprimer il y a plus de 20 ans un bon livre d'ailleurs, où cette différence est raportée au long" (Simon 1970, p. 291).
} 
books composed by Westerners. ${ }^{8}$ The 'report' is entitled "Lun Xifa jinian" 論西法積年 (About year-calculation according to the Western method) and found in Mei's Lixue yizen 曆學疑問 (Doubts concerning the study of astronomy) which the high official Li Guangdi 李光地 (1642-1718) had printed in 1699 and 1701. Li submitted the book in 1702 to the Kangxi emperor, who was interested in it. ${ }^{9}$ It may have been the difference between the Vulgata and Septuagint chronologies as explained in Mei's book that made him exclaim to missionaries: "What? Are your Classics (Scriptures) not clear [on the subject of chronology]?" 10 Mei wrote about this subject, among other things: ${ }^{11}$

Westerners (xiren 西人) say that from the Creation (kaipi 開闢) until now there only are more than 6000 years. [...] Moreover, what western books (xishu 西書) transmit is not unanimous (buyi 不一): their theories regarding the total number of years (since the Creation) are from the outset not uniform (xian you cenci 先有參差). [...]

According to Tiandi yi shu 天地儀書 (Book on the instruments [for measuring] heaven and earth), from the Creation until Chongzhen gengchen 崇禎庚辰 (1640) there are altogether more than 5630 years, and Shengjing zhijie 聖經直解 (Literal explanation of the Holy Scripture) says

\footnotetext{
${ }^{8}$ Notice that Mei met the Jesuits Prospero Intorcetta 殷鐸澤 in 1687/1688 (discussing the months and days in the Western calendar) and Antoine Thomas 安 多 in 1690; see Guo Mutian 1948, pp. 233-234; cf. Li Yan 1998 (1955), pp. 528/29, 531.

${ }^{9}$ Li Yan 1998 (1955), pp. 234 (preface by Li Guangdi, 1693, 4th month), 536 (printed in 1699, 10th month), 538 (printed in 1701; presented to the Throne, 1702, 10th month), 540 (1703, imperial esteem for the book). It was because of the book that the emperor summoned him to an audience during his tour of South China in 1705 (ECCP, p. 570; cf. Li Yan 1998, p. 540).

${ }^{10}$ Simon 1970, p. 490, note 3: "La chronologie de la Vulgate differe de celle des Septante. Le P. Parrenin explique à de Mairan (11 août 1730, BN, Frs 12 215, f. 135-174) comment K'ang Hi s'en trouva "scandalisé": "Quoi, disoit-il, vos Kims (Kings [經]) ne sont-ils pas clairs?" (f. 170).

${ }^{11}$ See juan 1 of Lisuan quanshu 曆算全書 (Complete writings on astronomy and mathematics), ff. 25a-26a, in: SKQSZB, 七集, vol. 139 (see also WYG, vol. 794, pp. 17-18). Apparently based on this text of Mei Wending, Jiang Yong 江永 (1681-1762) in his Shuxue 數學 (Study of numbers, ca. 1750?) reproduces the numbers of years from the Creation to 1640 in Tiandi yi shu (5630 yrs), Shengjing zhijie (6836 yrs) and ji-gu-ding yi (5730 yrs), or to 1628 in Yueli lizhi (6341 yrs); for these titles, see below (this and the next page). For the passage concerned in Shuxue see Congshu jicheng chubian no. 1328 (reproducing the Shoushan'ge congshu 守山閣叢書 edition of 1844), j. 1, p. 7; cf. Wu Liwei 2009, p. 308.
} 
that from the Creation until Chongzhen gengchen (1640) there are altogether 6836 years. ${ }^{12}$

According to Tongya [A comprehensive collection of refined knowledge, by Fang Yizhi 方以智, 1579-1671], the Westerners say (通雅按諸太西云) that from the Creation to Chongzhen jiashen 甲申 (1644) 6840 years have elapsed, but, relying on the ji-gu-ding yi 稽古定儀 they have fabricated one deduces that there have been only 5734 years. ${ }^{13}$

Yueli lizhi 月離曆指 [Observational methods of the movement of the moon, by Giacomo Rho 羅雅谷, 15931638] says that Chongzhen wuchen 崇禎龙辰 (1628) is the year 6341 [after the Creation]. ${ }^{14}$

Tianwen shiyong 天文實用 [The practical use of astronomy, by Johann Adam Schall von Bell 湯若望, 1592-1666] says: "The creation must have started with a vernal equinox". It also says: "Both China and the West regard Aries as the first constellation of the zodiac. Therefore at dusk

${ }^{12}$ In other words, Vulgata versus Septuagint chronology (5630 / 6836). It is unclear to which text Tiandi yi shu (apparently dating to 1640 or shortly afterwards) refers. Moreover, I could not find the number of 6836 years in Shengjing zhijie (completed in 1642, see below, note 121); this text mentions twice the number of years between Creation and Incarnation (see below, after note number 121), but it clearly uses a Vulgata chronology: 4000 years (a total not mentioned as such). The 'current' facsimile edition that I used (WXSB, vols. 4-6) is an undated edition published by the church of Wulin (Hangzhou) 武林天主堂梓行 (WXSB vol. 6, p. 2951) and is probably the first edition (1642 or shortly afterwards). Another copy of the Hangzhou edition that I consulted contains the same text (Paris, BnF Chinois 6729-6730). One might speculate for a moment that after the first edition the Vulgata chronology was changed into a Septuagint one (like the one Mei Wending is quoting), but this does not apply here, because reprints contain the same text as the undated Hangzhou edition. I also consulted the Peking reprints of 1739 and 1790 (Chinois 6722-6723 and 6740-6741) as well as an early nineteenth century edition of the 1790 reprint (Chinois 6742-6743) and a reprint of 1912 (Yanzhou 充州, copy in Leuven, Sinological Library).

${ }^{13}$ Cf. Tongya, juan 11 (天文), f. 33b/34a (又嘗按諸太西云 ...) in: SKQSZB，三集， vol. 203. It is not clear to me what kind of instrument ji-gu-ding yi precisely refers to.

${ }^{14}$ See CZLS, p. 136: 崇禎元年為總期六千三百四十一年 (j. 1，f. 10.a5), which means (6341 minus 1628): Incarnation in 4713 AM (annus mundi). There are many other examples of the same in Yueli lizhi, for example, p. 141 (j. 1, f. 21.a4): 總期 4846 (annus mundi) = Han Shundi Yangjia 2 guichou (133 CE), that is: 4846-133=4713; see also pp. 146, 162, 165, 167-168, 181-182, 205, etc. For the moment, I have no explanation for this rather unusual number of years (4713), halfway between a Vulgata (ca. 4000) and a Septuagint (ca. 5200) chronology. 
of the first day of creation Aries must have stood in midheaven. Today because of the precession of the equinoxes the constellation Aries has moved some ninety degrees from midheaven: counted in years this [moving] took 7.000 years, which fits with the annals of the Holy Scripture 與聖經紀年合." ${ }^{15}$

As to the period from the Creation to the Flood (hongshui 洪水), Tiandi yi shu 天地儀書 says: more than 1650 years, but Shengjing zhijie 聖經直解 says: 2242 years,

15 天文實用云開䦕初時適當春分又云中西皆以角為宿首因開䦕首日昏時角為中星
也今以恆星本行逆推約角宿退九十度必為中星計年則七千矣與聖經紀年合.
Tianwen shiyong is a text about Western astrology translated by Adam Schall by the end of 1644 (see Han Qi 韓琦 2011; see also Shi Yunli 2007, pp. 85-86), of which text there seems to have been preserved only one copy, viz. in the Biblioteca Nazionale Centrale di Roma (shelf-number: 72 C 535). According to Han Qi, it is a partial translation or adaptation of Ptolemy's Tetrabiblos. The sentences quoted, with only a few variants, by Mei Wending are found on f. $13 \mathrm{~b}$ of Tianwen shiyong (a punctuated text). The first part reads: 且開闢初時。適當春分。中西皆以是時日中星 為徵。(f. 13b4-5). The second part (after 又云) actually is a note (in smaller characters and in two columns instead of one) within the main text (f. 13b5-6) and inserted before the paragraph's end: 而西聖辨以實理。決其必然。另有專書詳之 (f. 13b6, not quoted by Mei). The note's last sentence is punctuated differently than expected: 與聖經。紀年正合, which suggests that jinian does not simply mean "annals" (of the Holy Scripture), but that it is a title and refers to the Bamboo Annals (Zhushu jinian 竹書紀年), which text plays an important role in the field of chronology (see the article by N. Standaert in this issue, p. 5). At first sight, interpreted in this way (jinian in Tianwen shiyong refers to the Bamboo Annals), Schall's statement seems to be an earlier testimony for the idea that Western chronology corresponds best with the chronology of the Bamboo Annals, an idea expressed by $\mathrm{Xu} F \mathrm{Fa}$ in his Tianyuan lili quanshu (1682) according to Antoine Gaubil (see footnotes 65 and 225 of Standaert's article just referred to). Gaubil overlooked, however, that the concerned passage (p. 335) in Xu Fa's text deals with the birth-year of the Buddha: Xu quotes a Song text saying that from that year to the beginning of the Shaoxing period (11311162) there have been 2.100 years. Xu then refers to Chinese Buddhist texts which place the birth of the Buddha in the $14^{\text {th }}$ year of king Zhao of the Zhou, a date $(968$ BCE) which is confirmed by the Bamboo Annals. Xu then concludes that the annals of the West (xitu jinian 西土紀年) and therefore the history of the West (xitu zhi shi 西土之史) correspond with the Bamboo Annals of China (中國竹書). It is clear that the West does not refer here to Europe but to India (see Zürcher 2007, pp. 273-274 and the appendix on 286-287: The Zhoushu yiji and the original Zhushu jinian). 
which makes a difference of 592 years. ${ }^{16}$ As to the period from the Flood to emperor $\mathrm{Ai}$ of the Han dynasty, the second year of Yuanshou, a gengshen year (1 BCE), when the Lord of Heaven incarnated, Tiandi yi shu says: more than 2340 years, but Shengjing zhijie says: 2954 years, which makes a difference of 614 years. ${ }^{17}$ Moreover, the yiquan 遺詮 ${ }^{18}$ says: 2946 years, ${ }^{19}$ which is eight years less than in Shengjing zhijie.

Since Mei quotes Fang Yizhi's Tongya (1666), he was not the first to point to differences in Western chronologies. Gaubil apparently was aware of this, because in an undated letter (1733?) he again complains that for already more than eighty years the Chinese, through the imprudence of some missionaries, know of the difference in years between the Vulgata and Septuagint chronologies. Missionaries after Ricci consulted the Father General about it, Adam Schall in particular. The answer praised the Septuagint chronology and affirmed that it would be very good to make use of it. ${ }^{20}$ Gaubil gives more details about this permission at the end of his Traité de la chronologie chinoise (Beijing, 27 Sept. 1749). It was given in a letter of $20 \mathrm{Dec}$ 1637 from the Jesuit superiors in Rome, answering a request of Adam Schall to use the Septuagint chronology "in order to accommodate the gene-

${ }^{16}$ This period is usually given as covering 1656 years in the Vulgata chronology, and 2242 in that of the Septuagint, see above, note 3. See also Grafton 2006, pp. 66, 71, 73 (difference of 1236 years).

17 Thus, for Tiandi yi shu the period Creation-Incarnation covers more than 3990 years $(1650+2340)[3990+1640=5630$, see above] and for Shenging zhijie 5196 years $(2242+2954)[5196+1640=6836$, see above]; in other words, Vulgata versus Septuagint chronology. For Shengjing zhijie, see below (notes 121-127).

${ }^{18}$ That is, Pangzi yiquan 龐子遺詮 (Explanations left by Mr. Pang, [i.e., Diego de Pantoja 龐迪我, 1571-1618]).

${ }^{19}$ Pangzi yiquan, however, also mentions 2954 years as well as 2242 years (see below, after note-number 125). As to Shengjing zhijie, one wonders whether Mei Wending or his source confounded it with Pangzi yiquan. But then the question is: in which text does one find 2946 ?

20 Simon 1970, p. 355: "Il y a longtemps que, par l'imprudence de quelques missionnaires, les Chinois savent la différence des années des 70 [=Septuagint] et de la Vulgate, ce mal est ici depuis plus de 80 ans, et dans ce que je vous ay anvoyé, vous avés vu que des Chinois en ont abusé. Les missionnaires qui succédèrent au P. Ricci consultèrent le R.P. Général; le R.P. Adam Schall fut un des principaux auteurs des lettres écrittes à Rome. A Rome on consulta; la réponse de Rome est ici dans les archives des Portugais, elle loue la chronologie des 70, et asseure qu'on fera très bien de s'en servir." 
rally accepted dates for China's first emperors." ${ }^{21}$ The letter first recommends that the missionaries should use a uniform chronology, and then gives permission to use the chronology proposed by Schall, a chronology confirmed by the Martyrologium Romanum (which placed the Creation at 5199 BCE $)^{22}$ and by the approval of its editor, cardinal Baronius (1538-1607), and supported by the authority of Church fathers. ${ }^{23}$ At the same time, it adds, one should not give Chinese converts the impression that it concerns a question that has been definitely settled by the Church or proven beyond doubt. ${ }^{24}$ However, maybe this very point (that the Septuagint chronology is

\footnotetext{
${ }^{21}$ Van Kley 1971, p. 362 (note 14). The request by Schall is, apparently, his letter of 1 Sept. 1634 to Theodor Busaeus, the General's Assistant for the German Province, which is reproduced in Bernard 1938, pp. 483-493 (cf. ARSI, Jap.Sin. 142, ff. 10r-13v); see especially p. 485; see also p. 492: table with the Septuagint chronology (Martyrologium Romanum: Flood in 2242 A.M. and Incarnation in 5199, before ' 584 ' insert "post diluvium"), compared with the Vulgata chronology (Flood in 1657 A.M. and Incarnation in 3950) found in Henricus Samerius SJ (ca. 1540-1610, who entered the Jesuit order in 1561 at Cologne), that is his Chronologia sacra ab orbe condito usque ad Christum (Antwerp: Verdussen, 1608), see p. 11 (consulted online, Google books, copy of Bibl. S.J. Les Fontaines, Chantilly). So "ex Samerio" (mentioned by Schall in his 1634 letter) does not refer to Scaliger, as Bernard assumed (see also o.c., p. 487), nor to the Samaritan Torah (von Collani 1998, p. 93, table; moreover, col. 2 is that of the Martyrologium). For the last page (with the concerned table) of this same letter (1 Sept. 1634) but addressed to the Vice-provincial Manuel Dias, see p. 120 of Sotheby's 1988 (cf. ARSI, Jap.Sin. 142, f. 9r). For this 1634 letter, see also von Collani 1998, pp. 88-93.

${ }^{22}$ First edition in 1583, revised in 1586 and 1589 by Caesare Baronio. The relevant entry for 24 December (the eve of the 25th) reads: "In the 5199th year of the creation of the world, from the time when in the beginning God created heaven and earth; from the flood, the 2957th year. [...]." The modern edition reads: "Unknown ages from the time when God created the heavens and the earth and then formed man and woman in his own image. Several thousand years after the flood, [...]" (see http:/ / catholic-resources.org/ChurchDocs/ChristmasProclamation.htm).

${ }^{23}$ Permission to use the Septuagint chronology was not restricted only to Jesuit missionaries. Claude Fleury (1640-1723) in his instruction for future missionaries of the Missions Etrangères de Paris (Mémoire pour les études des missions orientales, 1689) wrote: "Que si dans notre chronologie vous vous trouvez embarrassé à cause des histoires de la Chine dont vos Indiens ont sans doute une grande opinion, vous pouvez suivre la chronologie des Septante, qui vous donnera sept ou huit cent ans de plus ..." (quoted in Pinot 1932, p. 220).

${ }^{24}$ See Gaubil 1814, p. 284/85: “Le R.P. Général ayant reçu à Rome le Mémoire du R.P. Adam Schall nomma des réviseurs pour l'examiner. On ne dit pas si l'on consulta le Saint-Père. J'ai vu la lettre écrite de Rome le 20 décembre 1637, en réponse au Mémoire du
} 
not a dogma of the Church nor proven to be the right one) made it difficult for missionaries to consequently use a single chronology in their writings, all the more so as they had already introduced the Vulgata chronology before 1637. Still, after 1637 the Septuagint chronology became the dominant one in Chinese Christian texts (see Appendix 1: Survey of Chinese-Christian texts, seventeenth to eighteenth century: Vulgata or Septuagint chronology). However, the Vulgata chronology did not completely disappear, and, not surprisingly, even surfaced again towards the end of the eighteenth century (see towards the end of App. 1), when the Vulgata text of the Book of Genesis was translated (but not published).

\section{Vulgata chronology and the theory of 'six world ages' in Gezhi aolïe ${ }^{26}$ (before 1723), transmitted by way of Gewu qiongli bianlan'27 (Manila, 1607)}

An example of the use of a Vulgata chronology is found in Gezhi aolüe (before 1723). ${ }^{28}$ Before looking at the biblical chronology that it contains, an

R.P. Adam Schall. Dans cette lettre on recommande aux supérieurs de la mission, de faire suivre une chronologie uniforme par les missionnaires, en prêchant l'évangile; on ajoute qu'on peut sans scrupule suivre la chronologie chinoise, suivant le Mémoire du P. Adam Schall; qu'une telle chronologie est confirmée par l'autorité du martyrologe romain, et par le suffrage du cardinal Baronius, et est appuyée sur l'autorité des Pères de l'Eglise. On enjoint aux Jésuites de la Chine de ne pas faire entrendre aux Chinois, que la chronologie qu'on leur dit pouvoir suivre, est un point décidé par l'Eglise, ou un point évidemment démontré." This letter of 20 December 1637 apparently is not present in the Jesuit Archive in Rome: Alfons Väth, who consulted many documents in that Archive (see pp. 355360), also refers to the just quoted Traité (published in 1814) of Gaubil (Väth 1933, p. 110).

${ }^{25}$ This is despite the fact that during a meeting of missionaries in 1642 in Hangzhou they had agreed that all should use the Septuagint chronology (Christ was born 5199 years after the Creation, 2957 years after the Flood, etc.); see von Collani 1998, p. 95.

26 格致奧略 “Outline of the mystery [revealed through] investigating things (gewu 格物) and extending knowledge (zhizhi 致知)"; gezhi can also be translated as "natural science".

27 格物窮理便覽 “Handy compendium for investigating things and exhausting principles".

${ }^{28}$ Fujen 108R (cf. Dudink 1996, p. 28); CCT ZKW, vol. 4, pp. 1859-2026. It is a neatly written manuscript (which seems to imitate a printed work, see the title-page reproduced on p. 1859) that is dated the eighth month of Jiaqing $25(1820,7$ Sept.-6 Oct.), see f. 85 (p. 2026). The year ' 1820 ' is also mentioned once in the text: Jiaqing 
initial question to be addressed is what kind of text Gezhi aolüe exactly is. There seems to be only one copy of it, formerly preserved in the Zikawei Library at Shanghai, since ca. 1960 kept in Taibei and published for the first time in 1996 (CCT ZKW). In Louis Pfister's Notices biographiques et bibliographiques sur les Jésuites de l'ancienne mission de Chine, 1552-1773 (Shanghai, 1932), the author is regarded as an otherwise unknown European Jesuit with the Chinese name of Luo Mingyao 羅明堯 (see entry no. 453 on p. 984). ${ }^{29}$ Only rather recently did it become clear to me that the characters 羅 明堯 are a Minnan or Hokkien transliteration of the Spanish name Domingo, ${ }^{30}$ or more specifically, that Luomingyao means 'Dominican', and that Gezhi aolüe is a shortened version of Gewu qiongli bianlan by Tomás Mayor O.P. (哆媽氏), printed in Manila in 1607, one of the "Manila incunabula" (as Piet Van der Loon called them). ${ }^{31}$ If one compares how the authors of these two texts are mentioned, it is evident that Sanji Luomingyao 山畸羅明堯 is a Minnan or Hokkien transliteration of Santo Domingo (山廚羅明敖), in which two characters, however, were misread (廚/畸 and 敖/堯). In other words, the author of Gezhi aolüe is given as Tomás (Mayor), a member of the Order of Saint Dominic.

gengchen 嘉慶庚辰 (f. 43a, p. 1944), in what must be a later interpolation (for the dating "before 1723" see below after note-number 33). Apparently '1820' is the year in which a certain Andrew 安德肋 (f. 84b, p. 2025) copied Gezhi aolüe, and not, as I assumed earlier (Dudink 1996, p. 28), the year of its composition.

${ }^{29}$ I will not repeat here all the speculations about the identity of Luo Mingyao, author of Gezhi aolüe. See, Wylie 1964, p. 178 (or p. 142 in another edition); Dehergne 1973, no. 477 (p. 153), corrected in Dehergne 1999, p. 435/36: Luo Mingyao is a Chinese Jesuit, referring to JS 181, 2. Only Cordier (1901, no. 383) calls the author of Gezhi aolüe an anonymous person (Pelliot 1903, p. 116, sub no. 383: “Serait, d'après Wylie, ... , d'un Européen nommé 羅明堯 Lo Ming-yao"). See also Chen Yuan 1980, p. 112: Gezhi aolüe by Luo Mingyao (without further specifications). In my catalogue of Zikawei documents in Taibei, I also took Luo Mingyao as being the author (Dudink 1996, p. 28, sub 108R).

${ }^{30}$ See for example Luo-ming-ao in the Minnan transliteration of the name Domingo de Nieva 羅明敖黎尼媽, author of Memorial de la vida christiana en lengua China /Liaoshi zhengjiao bianlan 僚氏正教便覽 (Handy compendium of the orthodox tea-ching of God [py. liaoshi 僚氏 represents the Minnan transliteration of the Spanish 'Dios']; Manila, 1606); cf. Van der Loon 1966, p. 28; Fang Hao 1969, p. 1513. Hence-forth I will put "py." before a Pinyin transcription when it replaces a Minnan trans-literation (which I am not able to give) for Chinese characters as pronounced by Chinese around the year 1600 in Manila.

${ }^{31}$ Van der Loon 1966. 


\begin{tabular}{|l|ll|l|}
\hline Gezhi aolüe & 大西 羅明㙓 & 多瑪氏 & p. 1859 \\
\hline & 大西山畸羅明㙓 多瑪氏 & p. 1860 \\
\hline Gewu qiongli bianlan & 山廚羅明敖院 巴礼 多麻氏 & title page ${ }^{32}$ \\
\hline & \multicolumn{2}{|c|}{ 巴礼 哆媽氏 } & f. 1a1 \\
\hline & 山哆羅明敖 巴礼 & preface, f. 7a4 \\
\hline
\end{tabular}

The date of the compilation of Gezhi aolüe is not known. Besides the fact that a copy was made in 1820 (the sole copy circulating now), Gezhi aolüe must have existed before 1723, as can be deduced from the following note found on the last folio of the manuscript Shengjiao ge zhanli duoyin 聖教各瞻 禮鐸音 (Sermons for the Christian feast days): ${ }^{33}$

From the Creation until now, the first year [of Yongzheng (1723)], there are 6933 years. [From] the Creation until the Flood there are 2242 years, and until Abraham 922. [From] the Flood until the Incarnation there are 2954 years. [From] the Incarnation until now there are 1723 years. [See] Gezhi aolüe 格致奧略, Zhengshi lüeshuo 拯世略 說, Pangzi yiquan 龐子遺詮, Zhujiao yaozhi 主教要旨, Shengjing zhijie 聖經直解. ${ }^{34}$

Moreover, an edition preceding the present one (1820) must have been made in 1718 (see the interpolation, translated below in note 35), which is not necessarily the first edition.

${ }^{32}$ For a photograph of this title-page (Vienna copy), see Zhang Xiumin / Han Qi 2006, p. 699. In ARSI, Jap. Sin. I, 171 (the copy I have consulted by way of photographs taken for me by Nicolas Standaert), this title-page is partly damaged.

${ }^{33}$ Shengjiao ge zhanli duoyin will be reproduced (in 2013) in vol. 27 of CCT ZKW xubian. This is the document mentioned in my catalogue of the Zikawei collection at the Shanghai Library published in Sino-Western Cultural Relations Journal 33 (2011), pp. 1-41, viz. on p. 10 (SH 96), where, however, only the first juan 上卷 (consisting of two parts: $21+83$ folios) is described (acquisition number: 00095538B). Recently the second juan 下卷 was found (acquisition number: 00109573B, 123 folios, margin: 聖教鐸音).

34 自開闢至今〔雍正〕元年六千九百三十三年 開闢至洪水二千二百四十二年 至亞 罷浪九百廿二 洪水至降生二千九百五十四年 降生至今一千七百廿三年 格致奧略 拯世 略說 龐子遺詮 主教要旨 聖經直解. This is the first of a few annotations or remarks found on the last and unnumbered folio (without the running title shengjiao duoyin 聖教鐸音 in the margin), after folio 123 of xia juan 下卷 of Shengjiao ge zhanli duoyin (see preceding note), and which is not part of that text itself. As to the four texts referred to (apart from Gezhi aolüe), the latest text is Zhujiao yaozhi (1668, see below, after note-number 136); for the other texts, see below (the pages after note-number 116). 
Gezhi aolüe, a text of 84 folios (8 cols. of 24 characters) and not divided into juan, covers about 27 per cent of the three juan of Gewu qiongli bianlan [1607] (316 folios, continuously numbered, 9 cols. of usually 21 characters).

\begin{tabular}{|c|c|c|c|}
\hline $\begin{array}{l}\text { Gewu } \\
\text { qiongli } \\
\text { bianlan }\end{array}$ & fols. & $\begin{array}{l}\text { Gezhi aolüe } \\
\text { fols. }\end{array}$ & $\begin{array}{l}\text { CCT ZKW, } \\
\text { vol. } 4 \\
\text { pp. }\end{array}$ \\
\hline \multirow[t]{3}{*}{ juan 1} & 1a-45.a7 & 1a-21.a3 & $1860-1900$ \\
\hline & 45.a8-85.b4 & & \\
\hline & 85.b5-122.a1 & 21.a4-36.b4 & $1900-1931$ \\
\hline \multirow[t]{6}{*}{ juan 2} & 122.b-135.a4 & 36b.5-43.a2 & 1931-1944 \\
\hline & & $\begin{array}{l}\text { 43.a3-8 note dated } \\
1820 \text { (嘉慶庚辰) }\end{array}$ & 1944 \\
\hline & 135.a-145.a *36 & & \\
\hline & 145.a9-193.b7 & 43.b1-67.b3 & 1945-1991 \\
\hline & [ 194.a2-3 & $67 . b 4-5 * 37$ & 1991 ] \\
\hline & 193.b8-253.a4*38 & & \\
\hline
\end{tabular}

${ }^{35}$ f. 43.a3-8: "The histories of the ten thousand countries do not record the creation; only Judea in the Great West has preserved such a record. Since Heaven and earth were created, until the jiashen 甲申 year of Chongzhen 崇禎 [1644], there are 6844 years, in the midst of which the disaster of the Flood occurred: from the Flood until now, jiashen [1644], there are more than 4800 years, so Tang and Yu 唐虞 [Yao 堯 and Shun 舜, traditionally 2357 - 2255 - $2205 \mathrm{BCE}$ ] are only 500 to 600 years removed from the Flood. From the first year of Tao Tang 陶唐 [emperor Yao 堯, 2357 BCE] until the year Kangxi wuxu 戊戌 [1718] there are 4075 years, and until now, Jiaqing gengchen 庚 辰 [1820], there are another 102 years. So, from the first year of Tao Tang until Jiaqing gengchen there are altogether 4177 years" [4177-1820=2357]. The italicized parts contain the same text as on f. 16b of Zhu Zongyuan's Zhengshi lüeshuo 拯世略 說 (Summary talk of saving the world) [see also below, after note-number 129]: only where Zhu says that the Flood is more than 2000 years removed from the Creation, the present note changed this into: "Yao and Shun are 500-600 years removed from the Flood".

${ }^{36}$ These folios deal with the Chinese tradition of the Flood (hongshui 洪水), the origin of mankind, and the Three Sovereigns (sanhuang 三皇). For extensive quotations from these folios, see Fang Hao 1974a, pp. 459-461 (paragraphs 6, 7, 8 and 10).

37 The text here states that the Incarnation took place (cf. Martyrologium Romanum, 24 Dec.) in the 42nd year of Emperor Augustus 歐愚述道西沙 (py. Ou-yushu-dao-xi-sha; Gezhi aolüe: $m i$ 迷 instead of shu 述).

38 Paragraphs 節 3-7; subjects: the life of Christ (up to the Last Supper); the 


\begin{tabular}{|l|l|l|l|}
\hline & & & \\
\hline juan 3 & $253 . a 5$ & $67 . b 6$ & 1991 \\
\hline & $253 . a 6-264 . a 4$ & & \\
\hline & $264 . a 5-288 . b 5$ & $67 . b 7-78 . b 8$ & $1991-2013$ \\
\hline & $289 . a 1-298 . b 3$ & $79 . a 1-83 . a 4$ & $2014-2022$ \\
\hline & $298 . b-314 . b *^{39}$ & & \\
\hline & $315 . a-316 . b$ (終) & 83.a5-84.b3 (終) & $2022-2225$ \\
\hline
\end{tabular}

Like the other "Manila incunabula", one of the characteristics of Gewu qiongli bianlan is the use of Minnan transliterations for, usually, Spanish names, or terms like py. liaoshi 僚氏 for 'Dios' /God, or py. julüshi 居律氏 for 'cruz'/cross. ${ }^{40}$ When the Christian copyist compiled Gezhi aolüe from Gewu qiongli bianlan he was able several times to deduce from the context the equivalent of a certain Minnan transliteration in the standard language of the Chinese-Christian terminology of that time, in which case he skipped the Minnan transliteration. To give a few examples: py. Yalan 啞蘭 (Adam) and py. Yima 姨媽 (Eve) were replaced by Yadang 亞當 and Ewa 厄襪 (f. 38a, p. 1934), ${ }^{41}$ py. shanjiao julüshi 山礁居律氏 (santa cruz) [f. 265b] by shizijia 十 字架 (f. 68b, p. 1993), and py. shanjiao yilishe 山礁益禮社 (santa iglesia) [f. 289a] by egelexiya 厄格肋西亞 (ecclesia, the Church) [f. 79a, p. 2014]. On the other hand, given the absence of a Chinese translation of the entire Bible, the compiler (apparently not a Western missionary) did not recognize the quotation from the Book of Revelations (12:1) of Saint John, and so he left the characters (py. shan xian) 山羡 (= San Juan) unchanged. ${ }^{42}$ Also names other than biblical ones were often not recognized, for example py. kuilishe

'hostia' (py. e-shi-die 阿實㸘), the passion and death of Christ; the seven sacraments; the Creed.

${ }^{39}$ Refutation of Chinese 'superstitions': the Celestial Master Zhang, who is compared with the magician of the Pharaoh (Exodus 7:11, 22; 8:17); the Buddha Maitreya, etc. Notice that Fang Hao 1974a could not quote from these folios, as folios 289-316 are missing in the Leiden copy he consulted).

${ }^{40}$ For an incomplete list of such transliterations in Gewu qiongli bianlan, see Fang Hao 1974a, pp. 464-465. See also the list in Fang Hao 1974b, pp. 442-446.

${ }^{41}$ Gewu qiongli bianlan, f. 124b8-9: 男乃天主名之曰.啞蘭.解說乃土成之.女乃男人 為之. 名曰.微朥傲.解說乃男骨成之.又名姨媽 (py. wei-lao-ao 微朥傲 = virago, see Gen. 2, 23: "haec vocabitur virago quoniam de viro sumpta est"). Gezhi aolüe skipped 'virago' (微朥傲), another name for Eve.

${ }^{42}$ Gewu qiongli bianlan f. 267a2; Luis de Granada, Obras, vol. IV, p. 267, col. 2 (Simbolo, Part II, ch. XVII, beginning of § I); Gezhi aolüe, f. $69 b 7$ (p. 1995). Cf. Fang Hao 1974a, p. 465 (towards the end of the list). 
傀黎舍 $=$ Grecia $($ Greece $){ }^{43}$ but not py. yixidao 挨習道 = Egypt, that was replaced by the 'familiar' Eriduo 厄日多, or py. Suoxi 唆習 = José (Joseph) replaced by Ruose 若瑟. ${ }^{4}$ Surprisingly, the compiler skipped the name py. Mianzhilaoti-shi 綿知朥提氏 (= Mithridates VI, king of Pontus, who knew 22 languages), when the text speaks of the faculty of memory, and replaced it by Panduo-guo wang 般多國王 'the king of Pontus' (a kingdom that the text does not mention by name), apparently because he knew the story from the Xiguo jifa 西國記法 (The art of memory in the West) of Matteo Ricci, who only speaks of the king of Pontus 般多國王 without mentioning the king's name. ${ }^{45}$

\subsection{The Spanish source(s) of Gewu qiongli bianlan}

Another question is on which European text Gewu qiongli bianlan is based. The Spanish title page and old bibliographies already mention the book as the "Simbolo de la fe, in Chinese". ${ }^{46}$ This specifically refers to the famous Introducción del Simbolo de la Fe (1583) of Luis de Granada (1505-1588). Van der Loon showed for the first time that Gewu qiongli bianlan is "partly an adaptation" (1966, p. 33) of it, as two examples show: fol. 10.a (the first preserved folio in the Leiden copy consulted by Van der Loon) corresponds to Part I, chapter 17, introduction and paragraphs 1 and $2,{ }^{47}$ and fol. 98.6 cor-

\footnotetext{
${ }^{43}$ Gewu qiongli bianlan f. 30b1; Luis de Granada, Obras, vol. IV, p. 151, col. 2 (Simbolo, Part I, ch. XXXIII, § I); Gezhi aolüe, f. $15 a 7$ (p. 1888).

44 See Gewu qiongli bianlan, f. 158.b; Gezhi aolüe f. 49.b (p. 1957). On the same folio, however, the following names were not recognized and thus left unchanged: py. Luojiaoyin 羅礁因 = Dothain, py. Lüming 呂明 $=$ Ruben, and py. Xulao 須勞 $=$ Juda(s), see Genesis 37:17, 21, 25, 26.

${ }^{45}$ Gewu qiongli bianlan f. $18 \mathrm{b3}$ (昔者有一帝名曰 ...); Luis de Granada, Obras, vol. IV, p. 142, col. 2 (Part I, ch. 29): Mithridates Rey de Ponto; Gezhi aolüe, f. 8b1 (p. 1875); Xiguo jifa, f. 3 b2 (WX, p. 14).

${ }^{46}$ In the ARSI copy (Jap. Sin. I, 171) the Spanish title page is missing, but it is present in the copy in Vienna, see Zhang Xiping 2010, esp. p. 77: Simbolo de la Fe, en lengua y letra China. Compuesto por el Padre fray Thomas Mayor, de la orden de Sancto Domingo de la provincia del Sancto Rosario, en las Islas Philippinas (cf. van der Loon 1966, p. 31). See also the documents in Spanish at the end of the book (for which see Chan 2002, p. 230); for example, p. 332 (doc. no. 7, August 1607), referring to Gewu qiongli bianlan as "un libro q. se intitula cathecismo y doctrina christiana o simbolo de la fe, en lengua y caracteres de china."

47 "Manila incunabula", 1966, p. 33 (p. 32: photograph of fol. 10a); Luis de Granada, Obras, vol. IV, p. 87 col. 1; cf. Gezhi aolüe, f. 3.a7, p. 1864 (使勿污其巢 ..., without the picture).
} 
responds to Part I, chapter 21, § $1 .^{48}$ That by folio 10 the Chinese text has arrived already at chapter 17 (of the 38 chapters of Parte primera) shows that the Chinese text is not simply a translation, or even an exact summary, of the Introducción. In fact, the first folios (ff. 1.a-11.b) are based on the summary of Parte primera that Luis de Granada himself gave in the fifth and last part of his book. ${ }^{49}$ At the same time, Mayor made use of the main text so that he created his own summary of the text, not merely basing himself on de Granada's summary. For example, folios 19.a2-24.a7 (cf. Gezhi aolüe ff. 8.b4-12.b3, pp. 1875-1883) are a summary of ch. 30 of Parte primera, ${ }^{50}$ which is not summarized in Parte quinta. While juan 1 is mainly based on Parte primera, juan 3 is a selection of themes from Parte segunda. Judging from its titles, the paragraphs (jie 節) 1-4 of the first section (zhang 章) of juan 3 (not summarized in Gezhi aolüe) are based on chapter 3-6 of Parte segunda (31 chapters, treating sixteen excellences of Christianity). ${ }^{51}$ The fifth section (ff.

48 "Manila incunabula", 1966, p. 34 (p. 35: photograph of fol. 98b); Luis de Granada, Obras, vol. IV, p. 107 col. 2; cf. Gezhi aolüe f. 26.a6, p. 1910 (昔一大魚 ... 目長 二尺 ..., without the picture).

49 "Parte quinta de la Introduction del Simbolo de la Fe. La qual es un summario de las quatro principales Partes que se tratan en la dicha Introduccion. Capitolo primero. Del primer Articulo de nuestra fé que es Credo en Dios", untitled introduction (Luis de Granada, Obras, vol. V, p. 223 col. 1); Gewu qiongli bianlan, ff. 1.a1-1.b6, untitled introduction of the first juan 首卷, 章第一, 格物; Gezhi aolüe, ff. 1.a3-6 (p. 1860).

$\S \mathrm{I}$, "Primera razon, que procede por el movimiento de todas las criaturas corporales" (Obras, vol. V, p. 223 col. 2); Gewu qiongli bianlan, ff. 1.b7-3.a3 第一件事理 論有形體之 物須有功力助之乃能轉動; Gezhi aolüe, ff. 1.a7-2.a3 有形之物須有功力助之乃能轉動 (pp. 1860-1862).

§ II, "Segunda razon, por el natural instincto de los animales" (Obras, vol. V, p. 224 col. 1); Gewu qiongli bianlan, ff. 3.a4-11.b6: 第二件事理 論禽獸雖性偏亦有知覺運動 四節 首節乃禽獸自知巧計求食之事 次節乃禽獸自知保身之事 三節乃禽獸自知醫病之事 四 節乃禽獸自知愛子之事. Gezhi aolüe, ff. 2.a4-5.b7: 禽獸雖性偏亦有巧計求食保身醫病 愛子之事 (pp. 1862-1869).

50 "De los cinco sentidos exteriores, y primero de los ojos" (Luis de Granada, Obras, vol. IV, pp. 142 col. 2-146 col. 1). For quotations from Gewu qiongli bianlan ff. 19a-24a, see Fang Hao 1974a, pp. 457-458 (par. 4).

${ }^{51} \mathrm{f} .253 . \mathrm{a} 6$ 第一章釋正教自有正道. 正道便有正人以證正教;

1): f. $253 . b 8$ 首節釋正教正道乃僚士諪諪然示人無少差訛; cf. Segunda Parte de la Introducción del Simbolo de la Fe, cap. III: de la primera excelencia: ... los grandes errores del los Philosophos mayormente acerca de el ultimo fin del hombre;

2): f. 256a1 次節 釋正道不能屈正本主; cf. Segunda Parte, cap. IV: de la segunda excelencia: sentir altamente de Dios;

3): f. $257 \mathrm{a} 2$ 三節釋道既正自有律法勸人修善去惡; cf. Segunda Parte, cap. V: de la tercera excelencia: la rectitud, y santidad de las leyes, y de la doctrina que professa; 
264.a- 288.b) deals with martyrs (py. madishi 馬低氏), ${ }^{52}$ martyrdom being the fourteenth excellence (Parte segunda, ch. 16-28) and it contains, for example, the stories of the martyrdom of the virgins Eulalia (Olalla in Spanish; py. Alaiye 阿來耶) from the city of Mérida, py. Minglijiao 冥里朥 (ff. 269.b6-275.b1), and of Martina, py. Malaozhenya 瑪勞珍亞 (ff. 275.b2281.b7). ${ }^{53}$

I have not checked the entire text, but it is clear that Gewu qiongli bianlan is indeed mainly based on Luis de Granada's Introduccion del Simbolo de la $\mathrm{Fe}$. At the same time, as is the case with many Chinese texts compiled by missionaries, it is an adaptation of it and also contains parts not found in the main source used. In Gewu qiongli bianlan, for example, the sections in which the author refutes Chinese heterodox arts or teachings ${ }^{54}$ are evidently not from Introduccion. Another such example concerns the first two paragraphs (jie 節) of the first section (zhang 章) of juan 2, "History of the first ancestor and successive generations" (Shizu lidai jianji 始祖歷代鑑紀) and "Continuation of the chronology of former generations [before Christ]" (Chengxi qiandai linian 承繼前代歷年), which are the paragraphs on which I will focus below:

\begin{tabular}{|l|l|l|}
\hline Gewu qiongli bianlan & Gezhi aolüe & \\
第二卷 章第一 (f. 122.b1): & & \\
解始祖人元歷代鑑紀 & & \\
\hline
\end{tabular}

4): f. $258 b 7$ 四節 釋道教既正自有妙藥可療人魂罪病; cf. Segunda Parte, cap. VI de la quarta excelencia: que es sola ella tener Sacramentos que den Gracia.

For the paragraphs 3-4, see Van der Loon 1966, p. 37: text of the Ten Commandments (f. 258) and of the Creed (ff. 252.b-253.a, "which by keeping almost all the Hokkien elements is set apart from the rest of the book") and explanation of the seven sacraments (ff. 259.b-263.a, "the use of Hokkien characters has been abandoned altogether").

${ }^{52}$ Gezhi aolüe f. 67.b7: ma'erdi 瑪而底 (p. 1991).

${ }^{53}$ Gezhi aolüe ff. 70.b8-72.b8 (pp. 1997-2002) and ff. 73.a1-75.a4 (pp. 2002-2007). Cf. Luis de Granada, Obras, vol. IV, pp. 277.1-279.2 (capitolo XIX, Martyrio de la Virgen Sancta Olalla, 222-229) and pp. 279.2-282.2 (Capitolo XX, Martyrio de la Virgen Sancta Martina, 229-236). The next 'excellence' (no. 15, in chapter XXIX: De la decimaquinta excelencia de la Religion Christiana, que es, ser conformada con muchos y muy grandes Milagros) is also treated by Tomás Mayor in juan 3, f. 289.a1: 第二章釋真 變化法見之事 (法=發); cf. Gezhi aolüe f. 79.a1: 聖跡 (p. 2014).

54 See juan 3, the third and last section (f. 298.b1: 第三章釋邪術瞞人耳目), which was omitted in Gezhi aolüe (see the end of the table given above, cf. note 39). 


\begin{tabular}{|c|c|c|}
\hline $\begin{array}{l}\star^{55} \\
\text { ff. } 122 . b 3-135 . a 4\end{array}$ & $\begin{array}{l}\text { 始祖歷代鑑紀 } \\
\text { ff. 36.b5- 33.a2 }\end{array}$ & pp. 1931-1944 \\
\hline $\begin{array}{l}\text { 首節 兼辯中國鑑義 } \\
\text { ff. } 135.95-145 . a\end{array}$ & & $x^{56}$ \\
\hline $\begin{array}{l}\text { 次節承繼前世 } \\
\text { ff. 145.a9-193.b7 }\end{array}$ & $\begin{array}{l}\text { 承繼前代歷年 } \\
\text { ff. 43.b1- 67b5 }\end{array}$ & pp. 1945-1991 \\
\hline
\end{tabular}

Like the paragraph on Chinese history (ff. 135-145), there is no trace of these two paragraphs on biblical history and chronology (before Christ) in Introducción del Simbolo de la $\mathrm{Fe}^{, 57}$ and also not in other texts by Luis de Granada.

The main subject of Parte primera (and of juan 1) is that the world itself contains the proof that it was created by God. Before Mayor proceeded to the next subject (the excellencies of the Christian teaching), he felt compelled to tell his Chinese audience not merely the story of the Creation and the subsequent history of humanity told in the Bible, but also to refute Chinese traditions concerning the Creation and the Flood, Pan Gu 盤古 and the ancient emperors of China (ff. 135.a-145.a, omitted in Gezhi aolüe).

I have not been able to identify Mayor's Spanish ${ }^{58}$ source for these two paragraphs (ff. 122.b-135.a / ff. 145.a-193.b). Although most information is found in the Old Testament itself, Mayor did not directly base himself on the Bible, because at some point (see below) he follows the pseudo-Philo of Annius of Viterbo. In any event, his source is close to the Chronographia sive annales omnium fere regum, principum \& potentatuum, ab orbe condito ad hunc

${ }^{55}$ The text (f. 122.b2) mistakenly gives here the title of the first paragraph (Shoujie qian bian Zhongguo jianyi 首節兼辯中國鑑義), a title repeated on f. 135.a5, which is the right place for it (see also the table of contents, mulu 目錄, at the beginning of the book, which mentions the number of the folio (zhi 帙), viz. 135). Actually the title given to the entire section 章 should have been the title of a first paragraph (ff. 122.b3-135.a4), as Gezhi aolüe rightly did. Moreover, this juan consist of only one section and its title (Jie shizu renyuan lidai jianji 解始祖人元歷代鑑紀) does not cover the subjects of its seven paragraphs 節 (cf. above, note 38).

${ }^{56}$ The 2nd and 3rd column have been left blank and ff. 43.a3-8 (col. 2) and p. 1944 (col. 3) not filled in, because it concerns an interpolation (see above, note 35).

57 There is no relationship with Parte tercera, Tratado Segundo, and Capitolo XXVII: Las figures que en los tempos antiguos representaron la venida y el mysterio de Christo (Obras, vol. IV, pp. 488-506), which chapter treats Eve, Abel, Noah, Abraham, Jacob, Joseph, Jonas, Samson (§ I-VIII), Moses (§ XI), and Eliseus (§ XIII).

${ }^{58}$ Spanish, because of its transliterations of words like Dios, cruz, and San Juan (see above). 
annum Domini M.D.XLV (Rome, 1546) of Alexander Scultetus or Schultze $(1485-1564) .{ }^{59}$

\subsection{Vulgata chronology within a framework of 'six world ages' in Gewu qiongli bianlan, and reproduced in Gezhi aolüe and Renlei yuanliu 人類源流 (ca. 1700)}

The just mentioned two paragraphs (ff. 122.b3-135.a4 / ff. 145.a9-193.b7) are mainly narrative. The first covers the period up to the Flood and tells the stories of Adam, Eve, Cain, Abel, Seth, and Noah. The second paragraph continues this biblical history up to the birth of Christ: from Sem to Abraham; Lot and the story of Sodom; Isaac and Jacob; Joseph in Egypt; ${ }^{60}$ Moses, the Pharaoh, and the Exodus. ${ }^{61}$ The paragraph ends with mainly a list (with the number of years of each 'reign') of Israel's judges and kings, and after the Exile, of governors, etc., up to the time of king Herodes (Gewu: Ailuolishi 挨羅黎氏 / Gezhi: Eluode 厄落得), when Christ was born.

This history is presented within a framework of six "world ages" (aetates mundi) ${ }^{62}$ In Manuel Dias' Shengjing zhijie (1642) there is a framework of four "world ages" in 4000 years: Creation-Flood-Abraham-MosesIncarnation (see below, after note-number 118). Gewu qiongli bianlan, however, adheres to the theory of six "world ages", from Creation to Incarnation:

\begin{tabular}{|l|c|l|l|}
\hline Creation-Flood & 1656 & $\begin{array}{l}\text { f. 144.b3+5, } \\
156 . \mathrm{a} 9\end{array}$ & p. 1954 \\
\hline Flood-Abraham & 292 & $\begin{array}{l}\text { f. 148.a6 } \\
\text { f. 156.b1 }\end{array}$ & $\begin{array}{l}\text { p. 1948: } 922 \mathrm{yrs} \\
\text { p. 1954: 922 yrs }\end{array}$ \\
\hline Abraham-Moses (Exodus) & 505 & f. $184 . \mathrm{b} 2$ & p. 1978 \\
\hline Moses-Salomo (temple) & 480 & f. 188.a8 & p. 1983 \\
\hline Salomo-Exile & 430 & f. 189.b6 & p. 1985: $431 \mathrm{yrs}$ \\
\hline
\end{tabular}

\footnotetext{
${ }^{59}$ See the list of years during each of the six aetates mundi in "Ratio huius chronographiae" at the beginning of Scultetus' book (1546). The number of years and the totals for the first four periods $(1656,292,505,480)$ are the same as in Mayor's text; those of the fifth and sixth period differ only slightly $(440,583)$. Thus the total number of years for the six periods is 3959 (explicitly mentioned by Scultetus) instead of 3952 (a total not mentioned by Mayor).

${ }^{60}$ Joseph in Egypt: Gewu qiongli bianlan, ff. 157.a-173.a; Gezhi aolüe, ff. 49.a-56.a (pp. 1956-1968).

${ }^{61}$ Moses, the Pharaoh, and the Exodus: Gewu qiongli bianlan, ff. 174.b-186.b; Gezhi aolüe, ff. 57.a-62.b (pp. 1970-1981).

${ }^{62}$ For this concept, see e.g., Schmidt 1955 and Tristram 1985.
} 


\begin{tabular}{|l|c|l|l|}
\hline Exile-Incarnation & 589 & f. 193.b7 & p. 199 \\
\hline & 3952 & & c.q. 4583 years \\
& years & & \\
\hline
\end{tabular}

The (implicit) total of 4583 years for Gezhi aolüe is rather unusual, because (in addition to 431 for 430) Gezhi aolüe has 922 years for the period from the Flood to Abraham, instead of 292 years, ${ }^{63}$ which is quite close to the Septuagint dating of this period (942 years), although the 4583 years do not come close to the Septuagint dating of the period Creation - Incarnation (usually ca. 5200 years). ${ }^{64}$

Mayor's Gewu qiongli bianlan not merely presents the history from Creation-Incarnation within a framework of "world ages", each of them with its total number of years. It also shows for each period how one arrives at these numbers by mentioning the number of years of each Patriarch (that is, the age when the succeeding son was born) ${ }^{65}$ and the number of years that each ruler (Judge, King, or 'governor') reigned or was in office.

On the following pages, I reproduce in the form of tables (instead of in a narrative form as done in the original) the chronology from Adam to Christ, divided into six generations (shi 世) or world ages (aetates mundi), as mentioned in Gewu qiongli bianlan and Gezhi aolüe. To these two texts I add two versions of the manuscript Renlei yuanliu 人類源流 (The origin of mankind), which is also based on the two paragraphs (ff. 122.b3-135.a4 / ff. 145.a9-193.b7) of Mayor's Gewu qiongli bianlan. ${ }^{66}$ There is a minimum of

${ }^{63}$ As in Dias' Shengjing zhijie (see below, after note-number 116). It can hardly be a mistake of confounding 292 with 922, although such mistakes occur: Adam's son Seth lived for 912 years (Gewu f. 132.b4; Gezhi f. 41a2, p. 1940; see Genesis 5:8), but version 1 of Renlei yuanliu has '192' years (f. 8.b; CCT ZKW xubian, vol. 16, p. 18).

${ }^{64}$ Notice also that the person who inserted a note in the text (p. 1944) quotes Zhu Zongyuan's Zhengshi lüeshuo 拯世略說, a text that follows the Septuagint chronology (see below, after note-number 129). The use of different chronologies in seventeenth-century texts apparently could cause confusion later on.

65 The Patriarchs constitute the first, genealogical series: from Adam to Jacob. Then it goes from the latter's son Joseph by way of Moses and Joshua to the Judges of Israel. So there is a kind of switch halfway through the third period: Jacob moves to Egypt at the age of 130, when his son Joseph is 39, who dies 71 years later in Egypt, where 64 years later Moses is born, who at the age of 80 starts the Exodus.

${ }^{66}$ In a number of instances (especially in the second period: Flood-Abraham) Renlei yuanliu gives the Mandarin transliteration of a name with, rather curiously, the original Minnan transliteration as an alternative name or sound (you ming 又名/ you yin 又音). In some cases (Faleg, Abraham, Isaac, Moses) it also gives the meaning of a name, e.g., Faleg, the Vulgata name for Peleg: yiyan fenkai 譯言分開 (Peleg 
narrative in Renlei yuanliu (except for the introduction) ${ }^{67}$ and it concentrates on the chronological list, more or less in the form of tables. New here is that the list of 'rulers' (Patriarchs, Judges, Kings, and governors, etc.) from Adam up to Jesus is continued with a chronological list of popes (jiaozong libiao 教宗歷表), from Saint Peter to Innocentius XII (July 1691-Sept. 1700). ${ }^{68}$ That the list ends with Innocentius XII (in office since "Kangxi 30 xinwei" 康 熙三十年辛未/1691) without mentioning the numbers of years he reigned strongly suggests that Renlei yuanliu was composed not long after 1691, and in any event not later than ca. 1700. This more or less confirms that as late as 1683 copies of Gewu qiongli bianlan "could still be found not only in Manila but also in Fujian and even in Japan." ${ }^{69}$

means 'division', see Genesis 10, 25: “one was named Peleg, because in his time the earth was divided"). It is not clear to me from which source the author of Renlei yuanliu took this information.

${ }^{67}$ For the first folio (FJ 092R), an introduction (yin 引), see Xu Zongze 1949, p. 229; the text is very similar to Gezhi aolüe, ff. 37a-38a (pp. 1932-1934), and actually based on Gewu qiongli bianlan, ff. 123.a8-124.b9.

${ }^{68}$ In version 1 of Renlei yuanliu this is followed by biographies of saints from the Old Testament: Adam, Noah, Jona, Tobia (Tobith), and Abraham (not reproduced in CCT ZKW xubian vol. 16). I have not looked at these biographies in detail, and cannot tell whether they are based on Gewu or Gezhi. In any event, neither Gewu nor Gezhi deals with Jona and Tobia.

${ }^{69}$ Menegon 2009, p. 56. Van der Loon (1966, p. 36) suggests the possibility of two reprints of it in China before 1674 (on the testimony of Navarette, who speaks, however, in general of the 'Manila' Chinese publications of the Dominicans without mentioning a particular title); Beckmann 1968 (p. 202). If the text had been reprinted without doubt the Minnan transliterations would have been converted to those current in China, as happened with the two litanies of Mayor in the Hangzhou prayerbook of 1628, in which one finds, e.g. Ruowang 若望 for Johannes and not py. shan xian 山羡 (San Juan), or Saluoman 撒落滿 for Solomon and not py. shaoluowen 沙羅汶; see Brunner 1964, pp. 298 (f. 3), 307 (f. 15). 
Table: A Comparison of the six periods in Gezhi aolïe, Renlei yuanliu and Gewu qiongli bianlan ${ }^{70}$

The first period: Creation-Flood (1656 years) ${ }^{71}$

\begin{tabular}{|c|c|c|c|c|c|}
\hline & 1 & 2 & 3 & 4 & 5 \\
\hline & $\begin{array}{l}\text { p. 1934, 1938, } \\
1940-42\end{array}$ & $\begin{array}{l}\text { ff. 7b-15b } \\
\text { (pp. 16-32) }\end{array}$ & $\begin{array}{l}\text { ff. 4-17 (pp. } \\
497-524)\end{array}$ & $\begin{array}{l}\text { f. } 124,128, \\
132,133\end{array}$ & \\
\hline Adam & 亞當 & id. & id. & 啞蘭 & 130 \\
\hline Seth & 夕 & 色得 & 色德 & 夕 & 105 \\
\hline Enos & 厄諾斯 & 厄諾色 & 厄諾瑟 & 挨懦士 & 90 \\
\hline Cainan & 蓋因南 & 該南 & $\begin{array}{l}\text { id. } \\
\text { 又名 } \\
\text { 蓋因南 }\end{array}$ & 偕因南 & 70 \\
\hline Malalehel & 瑪勞黎乙 & 瑪辣肋爾 & $\begin{array}{l}\text { 瑪肋爾 } \\
\text { 又名 } \\
\text { 瑪勞黎一 }\end{array}$ & 瑪伤黎乙 & 65 \\
\hline Iared & 亞尼 & $\begin{array}{l}\text { 亞肋得 } \\
\text { 又音 } \\
\text { 耶尼 }\end{array}$ & $\begin{array}{l}\text { 耶尼 } \\
\text { 又名 } \\
\text { 亞肋得 }\end{array}$ & 耶尼 & 162 \\
\hline Enoch & 厄駱 & 厄諾格 & id. & 爺駱 & 65 \\
\hline Mathusalam & 麻誅沙南 & $\begin{array}{l}\text { 麻朱沙南 } \\
\text { 又音 } \\
\text { 瑪多撒辣 } \\
\text { (瑪都撒辣) }\end{array}$ & $\begin{array}{l}\text { 瑪都撒辣 } \\
\text { 又名 } \\
\text { 麻朱沙南 }\end{array}$ & 麻誅沙南 & 187 \\
\hline Lamech & 南益 & id. & $\begin{array}{l}\text { id. 一名 } \\
\text { 辣墨客 }\end{array}$ & 南益 & 182 \\
\hline Noe & 諾厄 & id. & id. & 懦挨 & \\
\hline
\end{tabular}

${ }^{70}$ Column 1, in the tables given below, concerns Gezhi aolüe (which hereafter I usually abbreviate as Gezhi); column 2 concerns Renlei yuanliu, version 1 (in vol. 16 of CCT ZKW xubian); column 3 concerns Renlei yuanliu, version 2 (FJ 092R, in vol. 26 of CCT ZKW xubian); and column 4 Mayor's Gewu qiongli bianlan (which hereafter I usually abbreviate as Gewu); "id." means: the name is the same as the preceding name on the same line. I omit names that are not part of the 'genealogy' such as Cain and his offspring (Gewu f. 128; Gezhi, p. 1937/38; cf. Genesis 4:17-22). I also omit the ages of the persons mentioned for the first two periods (Adam-Noah, Noah-Abraham), e.g., Adam died at the age of 930 years (p. 1938, cf. Genesis 5:5), and I mention in column 5 only the age when the son was born (like, e.g., Scultetus $1546 \mathrm{did})$. For the third period the opening column explains to which 'event' the number of years, mentioned in column 5, refers. For the other periods column 5 gives the number of reign-years of a judge or king.

${ }^{71}$ Cf. Genesis 5:1-32. See also Finegan 1998, p. 404 (Ussher); Grafton 2006, p. 71. 


\begin{tabular}{|l|l|l|l|l|l|}
\hline birth of & & & & & 500 \\
\hline Sem & 生 & id. & id. & 甚 & \\
\hline Ham & 岡 & 剛 & 岡 & 甘 & \\
\hline Iafeth & 雅弗德 & id. & id. & 耶肸 & \\
\hline $\begin{array}{l}\text { until the } \\
\text { Flood }\end{array}$ & & & & & 100 \\
\hline Period 1, total: & $1656^{* 72}$ & 1656 & $1656^{* 73}$ & 1656 & 1656 \\
\hline
\end{tabular}

The second period: Flood-Abraham ${ }^{74}$

\begin{tabular}{|c|c|c|c|c|c|}
\hline & 1 & 2 & 3 & 4 & 5 \\
\hline $\begin{array}{l}\text { two years } \\
\text { after the Flood } \\
\text { Sem begets: }\end{array}$ & & & & & 2 \\
\hline \multirow[t]{2}{*}{ Arfaxad } & 亞伐撒 & $\begin{array}{l}\text { id. 又音 } \\
\text { 亞兒發沙 }\end{array}$ & $\begin{array}{l}\text { id. 又名 } \\
\text { 亞兒伐沙 }\end{array}$ & 啞伐薩 & $35 \#$ \\
\hline & & 36 & & & \\
\hline \multirow[t]{2}{*}{ [Cainan] } & & 該南 *75 & & & \\
\hline & & 30 & & & \\
\hline Sale & 沙歷 & $\begin{array}{l}\text { 酒勒 又音 } \\
\text { 沙歷 }\end{array}$ & $\begin{array}{l}\text { id. 又名 } \\
\text { 沙歷 }\end{array}$ & 沙歷 & $30 \#$ \\
\hline Eber & 厄默 & $\begin{array}{c}\text { id. 又音： } \\
\text { 黑比耳 }\end{array}$ & $\begin{array}{l}\text { id. 又名： } \\
\text { 黑北爾 }\end{array}$ & 挨默 & 34 \\
\hline Faleg & 花憟 & $\begin{array}{c}\text { id. 又音： } \\
\text { 法勒客 }\end{array}$ & $\begin{array}{c}\text { id. 又名： } \\
\text { 法肋客 }\end{array}$ & 花憟 & $30 \#$ \\
\hline
\end{tabular}

${ }^{72}$ For the total of 1656 years, see Gewu f. 143. The text on this folio is not reproduced in Gezhi, but '1656' is mentioned on f. 48a (p. 1954); cf. Gewu, f. 156a. The '100' years after the time that Noah, at the age of 500, begot Sem are not explicitly mentioned, but they are implied when it is said that the Flood occurred when he was 600 years old (Gewu, f. 143.b7; Gezhi, p. 1942).

${ }^{73}$ First the text (Renlei yuanliu, version 2, FJ 092R) says that there were 1056 years from the Creation to the birth of Noah (f. 6a1), who was 600 years old at the time of the Flood, so for the period Creation -Flood the total is 1656 years (f. 6a2, but the character between qian 千 and bai 百 is not clear because of a handwritten correction); CCT ZKW xubian vol. 26, p. 501. For 1056 instead of 1656, see below, after note-number 119 (Shengjing zhijie 聖經直解) and after note-number 144 (Daoxue jia zhuan 道學家傳 (Family tradition of the study of the Way)).

${ }^{74}$ Gewu ff. 145v-148r; Gezhi ff. 43b-45a (pp. 1945-1948). Cf. Genesis 11:10-26).

${ }^{75}$ Cainan (between Arfaxad and Sale), often called Cainan II (the first Cainan was a great-grandson of Adam), is absent in the Hebrew text of Genesis 11:12, but present in the Septuagint text of it, as well as in the genealogy of Jesus in the Gospel of Luke (3:36); see Mangenot 1912, cols. 723 and 724; Von den Brincken 1957, p. 169; Tristram 1985, p. 182. See also Castorano (below, note 150). 


\begin{tabular}{|c|c|c|c|c|c|}
\hline Reu & $\begin{array}{l}\text { 黎黎宇 } \\
\end{array}$ & $\begin{array}{c}\text { 樓 又音: } \\
\text { 黎黎于 }\end{array}$ & $\begin{array}{c}\text { id. 又名: } \\
\text { 黎黎宇 }\end{array}$ & 黎黎宇 & $32^{\#}$ \\
\hline Sarug & 沙落 & $\begin{array}{l}\text { 撒路額 } \\
\text { 又音：沙駱 }\end{array}$ & $\begin{array}{l}\text { id. } \\
\text { 又名: 沙路 }\end{array}$ & 沙駱 & $30^{\#}$ \\
\hline Nahor & 那骨 & $\begin{array}{l}\text { 那各爾 } \\
\text { 又音: 那骨 }\end{array}$ & $\begin{array}{l}\text { id. } \\
\text { 又名: 那骨 }\end{array}$ & 那骨 & $29 \#$ \\
\hline Thare & 礁禮 & $\begin{array}{l}\text { 大勒 } \\
\text { 又音: 礁禮 }\end{array}$ & $\begin{array}{l}\text { id. } \\
\text { 又名: 樵禮 }\end{array}$ & 礁禮 & 70 \\
\hline Abraham & 亞把郎 & 亞罷郎 & 亞巴浪 & 啞貓朥漢 & \\
\hline Period 2, total: & $\begin{array}{l}922^{* 76} \\
\text { (p.1948) }\end{array}$ & $920^{+}$ & $292 * 77$ & $\begin{array}{l}292 \\
\text { (f. 148.a6) }\end{array}$ & 292 \\
\hline
\end{tabular}

The third period: Abraham - Moses (505 years) ${ }^{78}$

\begin{tabular}{|l|l|l|l|l|c|}
\hline & 1 & 2 & 3 & 4 & 5 \\
\hline $\begin{array}{c}\text { Abraham } \\
\text { begets: }\end{array}$ & & & & & $100^{* 79}$ \\
\hline $\begin{array}{c}\text { Isaac } \\
\text { begets: }\end{array}$ & 依撒 & 依撒客 & $\begin{array}{l}\text { 依撒 又名 } \\
\text { 依撒客 }\end{array}$ & 依捒 & $60^{* 80}$ \\
\hline
\end{tabular}

76 The numbers with a hash (\#) are absent in Gezhi aolüe (pp. 1945-1948) apparently because it gives a total of 922 years for this period (close to the Septuagint number of years for this period: 942 , see above).

77 The total number of years for the period Creation-Abraham is said to be 1948 (see f. 8a), viz. 1656 (f. 6a) + 292 (f. 8a); CCT ZKW xubian vol. 26, pp. 501, 505. The other version of Renlei yuanliu (f. 9b-10a) has "more than 920 years" for the period from Noah to Abraham (whose birth is placed during the reign of the Xia emperor Mang (Xia chao di Mang 夏朝帝芒), traditionally 2014-1996 BCE); CCT ZKW xubian vol. 16, p. 20/21. At the same time this version of the Renlei yuanliu keeps the numbers of years (most of which numbers Gezhi aolüe omitted) that make up a total of 292 (and not 920+); the addition of Cainan II (see note 75) means only 30 years more.

${ }^{78}$ Gewu, ff. 149-184; Gezhi, ff. 45a-61a (pp. 1948-1978). Cf. Finegan 1998, p. 170: "From Abraham to Moses and the exodus from Egypt, [the Chronicle of] Eusebius finds that the Septuagint, Hebrew, and Samaritan texts all agree on a total of 505 years" (see also Table 78 on p. 171).

${ }^{79}$ Gewu, f. 149.a3; Gezhi, f. $45 . b 1$ (p. 1949). Scultetus (1546) has $75+25$ : at the time of his vocation Abraham was 75 years old, and 25 years later Isaac was born.

${ }^{80}$ Gewu, f. 156.b3; Gezhi, f. $48 . a 7$ (p. 1954). 


\begin{tabular}{|l|l|l|l|l|c|}
\hline $\begin{array}{l}\text { Jacob } \\
\text { moves to } \\
\text { Egypt }\end{array}$ & 雅各 & 雅各伯 & 雅歌伯 & 沙果 & $130^{* 81}$ \\
\hline $\begin{array}{l}\text { Joseph, his } \\
\text { son, then 39, } \\
\text { dies when he } \\
\text { is } 110 \\
(-39=71)\end{array}$ & 若瑟 & id. & id. & 唆習 & $71^{* 82}$ \\
\hline $\begin{array}{l}\text { period } \\
\text { between the } \\
\text { death of }\end{array}$ & & & & & \\
$\begin{array}{l}\text { Joseph and } \\
\text { the birth of } \\
\text { Moses }\end{array}$ & & & & & $64^{* 83}$ \\
\hline Mo(y)ses & 美瑟 & 每瑟 & id. & 毛以西氏 & $80^{* 84}$ \\
\hline Period 3, total: & & & & & $505^{* 85}$ \\
\hline
\end{tabular}

${ }^{81}$ Gewu, f. 171.a8; Gezhi, f. $55 . b 3$ (p. 1967). Jacob dies at the age of 147: Gewu, f. 172.a2; Gezhi, f. 55.b7. According to Gewu, f. $156 . b 7$ (cf. Gezhi, f. 48b1, 49a1; pp. 1955, 1956), when Jacob was more than 100 years old, he had begotten twelve sons. Renlei yuanliu (FJ 092R) tells that Jacob was 92, when he begot Joseph (f. 8.b3; CCT ZKW xubian vol. 26, p. 506).

82 Joseph is 39, when Jacob moves to Egypt (Gewu, f. 172.a9; Gezhi, f. $56 . a 2$ (p. 1968), and dies at the age of 110 (Gewu, f. 173.a2; Gezhi, f. 56.a3. The number of '71' is given by Scultetus (1546): "A 39 anno Ioseph vel ab ingressu Iacob in Aegyptum, ut compleantur 110 anni quibus Ioseph vixit Geñ. ultimo [Genesis 50:26] sunt anni 71".

${ }^{83}$ Gewu, f. 174.b6; Gezhi, f. $57 . a 3$ (p. 1970); Renlei yuanliu version 1, f. 11a (CCT ZKW xubian vol. 16, p. 23). Scultetus (1546): "Anni intermedii post illos 286 et ante natum Mosen non [...] ex sacris literis colligitur, tamen ex premissis fuisse annos 64" (286: $25+60+130+71 ; 286+64=430$, plus 75 [age of Abraham at his vocation] = 505) Scultetus remarks that "Philo in breviario temporum" (i.e. Annius of Viterbo) has the same number of years for this period $(425+80)$.

${ }^{84}$ Gewu, f. 184.b2; Gezhi, f. $61 . a 5$ (p. 1978).

${ }^{85}$ Gewu, f. 184.b3; Gezhi, f. 61.a6. Renlei yuanliu, version 2 (CCT ZKW xubian vol. 26 , p. 506) gives a total of 720 years, which is 215 years more; 720 is apparently $75+645$ (for ' 645 ', see Barr 1985, p. 605; for '215', pp. 587-588). 
The fourth period: from the Exodus to the start of the building of the Temple in Jerusalem $\left(480\right.$ years) ${ }^{86}$

\begin{tabular}{|c|c|c|c|c|c|}
\hline & 1 & 2 & 3 & 4 & 5 \\
\hline $\begin{array}{l}\text { Moses (after } \\
\text { the Sinai) }\end{array}$ & $\begin{array}{l}\text { f. } 62 . b 2 \\
\text { (p.1981) }\end{array}$ & & & f. $186 . b 3$ & 40 \\
\hline Iosue & 和稅 & id. & id. & 和稅 & 17 \\
\hline Othonihel & 阿多尼一 & 阿多尼 & id. & 阿多尼乙 & 40 \\
\hline Ahoth (Ehud) & 哀鬱 & id. & id. & 哀㯺 & 80 \\
\hline $\begin{array}{l}\text { Barac \& } \\
\text { Debbora }\end{array}$ & $\begin{array}{l}\text { 貓六交 } \\
\text { 黎巫朥 }\end{array}$ & $\begin{array}{l}\text { 毛六教 } \\
\text { 黎扶老 }\end{array}$ & $\begin{array}{l}\text { id. } \\
\text { id. }\end{array}$ & $\begin{array}{l}\text { 貓六交 } \\
\text { 黎巫朥 }\end{array}$ & 40 \\
\hline Gedeon & 奚黎王 & 奚理望 & id. & 奚黎王 & 40 \\
\hline Abimelech & 亞微冥歷 & $\begin{array}{l}\text { 若未明歷 } \\
(30 \mathrm{yrs})\end{array}$ & id. & 啞微冥歷 & 3 \\
\hline Thola & 倒朥 & 道勞 & id. & 倒朥 & 23 \\
\hline Iair (Jair) & 怀乙 & 怀一 & id. & 怀乙 & 22 \\
\hline Iepthae & 翟短 & 隙短 & id. & 翕短 & 6 \\
\hline Israhel (Ibzan) & 亞迷產 & id. & id. & 啞迷產 & 7 \\
\hline $\begin{array}{l}\text { Ahialon } \\
\text { (Elon) }\end{array}$ & 亞希郎 & id. & id. & 啞希朗 & 10 \\
\hline Abdon & 押朗 & id. & id. & 押朗 & 8 \\
\hline Samson & 三順 & id. & $\begin{array}{l}\text { id. } \\
\text { 即三算 }\end{array}$ & 三順 & 20 \\
\hline Heli (Eli) & 奚里 & 后奚利 & id. & 奚里 & 40 \\
\hline Samuel & 沙鬱 & id. & $\begin{array}{l}\text { id. 又名 } \\
\text { 撒阿耳 }\end{array}$ & 沙鬱 & 40 \\
\hline David & 達味 & id. (41) & id. (40) & 朥蜜 & 40 \\
\hline $\begin{array}{l}\text { Solomon } \\
\text { (Salomon) }\end{array}$ & 撒落滿 & 撒辣滿 & id. & 沙羅汶 & 4 \\
\hline Period 4, total: & 480 & $\begin{array}{l}\text { no total } \\
\text { given } * 87\end{array}$ & $\begin{array}{l}\text { no total } \\
\text { given }\end{array}$ & $480^{88}$ & 480 \\
\hline
\end{tabular}

${ }^{86}$ Barr 1985, p. 605: “The ... period, from the Exodus to the start of the temple building, is unequivocally settled by I Kings vi.1: this period was 480 years. This overrides a great deal of fragmentary chronological material about the Judges, Samuel, Saul and David: furnished with this major bracket, the chronologist did not have to trouble too much about the details that lay within it." Cf. Finegan 1998, p. 173.

${ }^{87}$ Renlei yuanliu (version 1) mentions 40 years for Solomon with which the fifth period starts (combining the 4 years at the end of the fourth period with the 36 years at the beginning of the fifth period). Renlei yuanliu (version 1) adds that the reign of Solomon coincides with that of king Zhao of the Zhou dynasty (he Zhong li wei Zhou Zhao wang zhi shi 合中曆為周昭王之世); CCT ZKW xubian vol. 16, p. 27 (f. 13a). 
The fifth period: from the building of the Temple to its destruction and the Exile (430 years) $)^{89}$

\begin{tabular}{|c|c|c|c|c|c|}
\hline & 1 & 2 & 3 & 4 & 5 \\
\hline $\begin{array}{l}\text { Solomon } \\
\text { (after Temple } \\
\text { building) }\end{array}$ & & & & & 36 \\
\hline Roboam & 羅薄盘 ${ }^{90}$ & id. & id. & 羅磨昂 & 17 \\
\hline Abias & 亞彼亞 & 亞比亞 & id. & 啞美耶氏 & 3 \\
\hline Asa & 亞撒 & id. & id. & 啞沙 & 41 \\
\hline Iosaphat & 藥撒法 & id. & id. & 呂沙伐 & 25 \\
\hline Ioram & 藥郎 & id. & id. & 邀南 & 8 \\
\hline Ozias & 阿祭亞 & 阿西亞 & id. & 阿施啞氏 & 1 \\
\hline Athalia & 亞礁里亞 & 亞爵理亞 & id. & 啞礁里耶 & 6 \\
\hline Ioas & 帝華 & id. & id. & 華氏 & 40 \\
\hline Amasias & 亞麻祭亞 & 亞瑪西亞 & id. & 啞麻施耶 & 29 \\
\hline Azarias & 亞撒里亞 & 亞撒理亞 & id. & 啞沙里啞氏 & 52 \\
\hline Ioathan & 扶華淡 & 扶華亘 & id. & 扶華淡 & 16 \\
\hline Achaz & 亞交 & id. & id. & 啞膠氏 & 16 \\
\hline Ezechias & 亞西已亞 & 厄西以亞 & id. & 啞西已耶氏 & 29 \\
\hline Manasses & 瑪納森 & 瑪納孫 & $\begin{array}{l}\text { id. } \\
55\end{array}$ & $\begin{array}{l}\text { 馬那西氏 } \\
55\end{array}$ & 56 \\
\hline Amon & 亞滿 & id. & id. & 啞汶 & 2 \\
\hline Iosias & 若西亞 & id. & 若細亞 & 唆始耶氏 & 31 \\
\hline Iohahaz & 唆亞交 & 穌亞交 & id. & 唆啞咬 & 3 months \\
\hline Ioiachim & $\begin{array}{l}\text { 華謹 } \\
\end{array}$ & id. & id. & 華謹 & 11 \\
\hline
\end{tabular}

${ }^{88}$ For 480, see Gezhi f. $63 . b 7$ (p. 1983); Gewu f. 188.a8 (quoted in Fang Hao 1974a, p. 462 , column 3 .

${ }^{89}$ Gewu (f. 189.b5) has a total of 430 years instead of 431 (Gezhi p. 1985), because Manasses reigned for 55 years (cf. IV Rg 21:1) instead of 56 (Gezhi p. 1984). Cf. Barr 1985 , p. 605" "if one simply reads from Kings all the numbers of years recorded for the kings of Judah, from the fourth year of Solomon to the destruction of kingdom and temple, and adds them up, the number is: 430. The actual chronology could have been shorter than this, and historically it certainly was." Stultetus (1546) has 440, because in the Septuagint text Amon is said to have reigned for 12 instead of 2 years (cf. Von den Brincken 1957, p. 169).

${ }^{90}$ For the names of Roboam to Ozias, and of Manasses to Iosias the characters in Gezhi are the same as in Matthew's genealogy of Jesus in Aleni's Tianzhu jiangsheng yanxing jilüe 天主降生言行紀略 (Summary record of the words and deeds of the Incarnated Lord of Heaven), j.1, f.3 (CCT ARSI, vol. 4, pp. 47-48). 


\begin{tabular}{|l|l|l|l|l|c|}
\hline Ioiachin & $-(子)$ & - & 化斤 & 華謹 & 3 months \\
\hline Sedecias & 西黎已亞 & 西利以亞 & $\begin{array}{l}\text { 西黎以 } \\
\text { 亞 }\end{array}$ & 西黎已啞氏 & 11 \\
\hline Period 5, total: & 431 & - & $499 * 91$ & 430 & 431 \\
\hline
\end{tabular}

The sixth period: from the destruction of the temple and the exile, to the Incarnation (589 years) ${ }^{92}$

\begin{tabular}{|c|c|c|c|c|c|}
\hline & 1 & 2 & 3 & 4 & 5 \\
\hline Babylonian captivity & p. 1985 & f. $13 b$ & f. $13 a$ & f. 190.a & 70 \\
\hline Zorobabel & 唆羅貓蜜 & 穌羅貌密 & id. & 唆羅貓蜜 & 58 \\
\hline $\begin{array}{l}\text { Resa Mysciollam } \\
(\text { Resa }) *{ }^{93}\end{array}$ & 黎落撒 & id. & id. & 黎螺沙 & 66 \\
\hline Iohanna & - & - & 羡那 & 羡那 & 53 \\
\hline \multirow{2}{*}{ Iudas (Ioda) } & 法郎 & id. & id. & 孚朥氏 & 14 \\
\hline & & & & sub-total & 191 \\
\hline Iosephus (Iosech) & 須習浩 & id. & id. & 須習浩 & 7 \\
\hline Abner Semei (Semei) & 押里 & 押理 & id. & 押哩 & 11 \\
\hline $\begin{array}{l}\text { Elich Matathias } \\
\text { (Matthathiae) }\end{array}$ & 厄里 & 厄利 & id. & 挨里 & 12 \\
\hline Asar Maat (Maath) & 亞撒望 & id. & id. & 啞沙朥萬 & 9 \\
\hline $\begin{array}{l}\text { Nagid Artaxat } \\
\text { (Nagge) }\end{array}$ & 瑪訖 & id. & id. & 媽訖 & 10 \\
\hline Agai Helly (Esli) & 亞郎 & 亞耶以 & id. & 啞涯以 & 8 \\
\hline $\begin{array}{l}\text { Maslot Naum } \\
\text { (Nahum) }\end{array}$ & 瑪咬羅鬱 & 瑪穌羅邑 & id. & 媽唆羅鬱 & 7 \\
\hline $\begin{array}{l}\text { Amos Scyrach } \\
\text { (Amos) }\end{array}$ & 亞毛斯 & 亞貌斯 & id. & 啞毛士 & 14 \\
\hline $\begin{array}{l}\text { Matathias Siloa } \\
\text { (Matthathiae) }\end{array}$ & 麻礁知亞 & 麻爵知 & id. & 麻礁知涇 & 10 \\
\hline $\begin{array}{l}\text { Iosephus iunior } \\
\text { Arses (Ioseph) }\end{array}$ & 西集浩 & 西濟浩 & id. & 須習浩 & 60 \\
\hline
\end{tabular}

${ }^{91} 499$ years (f. 13b1), that is from the fourth year of king Solomon to the return from the Babylonian captivity, which had lasted 70 years (f. 13a). Notice that the text (f. 13a) still uses Minnan transliterations: py. maolilunya 貓里倫亞 = Babylonia, and its king py. Nawugaonuoluosu 那巫高諾羅蘇 = Nabuchodonosor (Nebuchadnezzar), as in Gezhi f. 64.b5 (p. 1985) and Gewu f. $189 . b 8$ (lun 侖 for 倫; ye 耶 for ya 亞; $n u o$ 懦 for 諾; suo 梭 for $s u$ 蘇).

${ }^{92}$ Gewu, ff. 189.b7-193.b7; Gezhi, ff. 64.b4-67.b3 (pp. 1985-1991).

${ }_{93}$ Here and below, between parentheses are the names that differ in the genealogy of Christ in the Gospel of Luke, 3:24-27 (Vulgata). 


\begin{tabular}{|c|c|c|c|c|c|}
\hline $\begin{array}{l}\text { Ianeus Hircanus } \\
\text { (Iannae) }\end{array}$ & 夷里干諾 & 以理甘諾 & id. & 夷尼干懦 & 16 \\
\hline & & & & sub-total & 164 \\
\hline $\begin{array}{l}\text { Hasmonean } \\
\text { dynasty of the } \\
\text { Maccabees: }\end{array}$ & p. 1988 & & & f. 192.a & \\
\hline Matathias & $\begin{array}{l}\text { 毛礁知亞 } \\
\text { (no years } \\
\text { given) }\end{array}$ & $\begin{array}{l}\text { 貌爵濟亞 } \\
50\end{array}$ & $\begin{array}{l}\text { id. } \\
50\end{array}$ & $\begin{array}{l}\text { 媽礁知啞氏 } \\
\text { - }\end{array}$ & $\begin{array}{r}x=5 ? \\
\quad * 94\end{array}$ \\
\hline Iudas & 孚朥 & 享勞 & $\begin{array}{l}\text { 享勞 } \\
\text { 一名 孚 } \\
\text { 勞 }\end{array}$ & 孚朥氏 & 5 \\
\hline Jonathan & 分那達 & id. & id. & 分那達氏 & 19 \\
\hline Simon & 心文 & id. & id. & 心文 & 8 \\
\hline Hyrcanus & 奚里干那 & 以理千那 & id. (干) & 奚尼干懦 & 26 \\
\hline Aristobulus & $\begin{array}{l}\text { 啞里實道 } \\
\text { 無呂 }\end{array}$ & $\begin{array}{l}\text { 亞理實道 } \\
\text { 無呂 }\end{array}$ & $\begin{array}{l}\text { 亞利實 } \\
\text { 道 } \\
\text { 無吕 }\end{array}$ & $\begin{array}{l}\text { 啞尼實道 } \\
\text { 無吕 }\end{array}$ & 1 \\
\hline Alexander Jannaeus & 亞黎雙螺 & 亞利桑羅 & id. & 啞黎隻隻螺 & 27 \\
\hline Salome Alexandra & 亞黎雙勞 & 亞利桑勞 & id. & 啞黎雙朥 & 9 \\
\hline Hyrcanus II & 奚里干懦 & 亞理干度 & id.*95 & 奚尼干懦 & 34 \\
\hline
\end{tabular}

94 The total for this period is 589 (see e.g. Barr 1985, p. 607), but the sub-totals I count are: $70,191,164,159$, which gives a total of 584 , so five years are missing. Scultetus (1546) mentions a total of 586 years as well as the sub-totals 70, 191, 164, and 161. He does not include Matathias (starting the next period of 161 years with Iudas Macchabeus) and he dates the Incarnation in the year 32 of king Herodes (instead of 30), the reason why his subtotal is 161 (and not 159). As Scultetus remarks, also for Philo (that is Annius of Viterbo; see below, after note-number 99) the period from Iudas Macchabeus to the birth of Christ is 161 years.

${ }^{95}$ By way of the layout, both versions of Renlei yuanliu 'insert', after Hyrcanus II, king Antigonus (py. anzhi'aonuo 安知敖懦 / py. anji'aonuo 諳濟敖懦 [ 諳濟教懦 ] ) without mentioning the number of years he reigned, like in Gewu (f. 193) and Gezhi (f. 67.a1+4, p. 1990); see CCT ZKW xubian vol. 16, p. 32 (f. 15b), and vol. 26, p. 523 (f. 17a). Other persons mentioned in the narrative (Gewu, ff. 192.b-193.b, and Gezhi, pp. 1989-1990) are Pompeius (py. pangbiyou 旁粉由) and Antipater (py. anzhibachulü 安 知巴廚呂); the Aristobulus who is mentioned here for a second time is Aristobolus II, father of Antigonus and Alexander (py. yalishuangli 亞黎雙黎, f. 193.a6 / f. 67.a1, p. 1990). 


\begin{tabular}{|l|l|l|l|l|r|}
\hline Roman rule: & & & & & \\
\hline Herodes & 厄落得 & 厄樂得 & 厄落得 & 挨羅氏 & 30 \\
\hline Period 6, total: & & & & sub-total & 159 \\
\hline $\begin{array}{l}589 \\
\text { (p. 1991) }\end{array}$ & - & $564^{* 96}$ & $\begin{array}{l}589 \\
\text { (f.193.b7) }\end{array}$ & 589 \\
\hline
\end{tabular}

While the approximate duration $(586,587,589$, or 590 years) of this period is well known, ${ }^{97}$ there is not much historical or biblical information about what happened in Juda (or Yehud province) after the return from 70 years of Babylonian captivity, during 355 years of Persian and Hellenistic domination, up to the beginning of the Hasmonean kingdom of the Maccabees. ${ }^{98}$ So it is surprising to find here names of 'shepherds, overseers' (mu 牧 or simu 司牧) with the number of years they were 'in office' (zaiwei 在位). In the Chronographia of Alexander Scultetus one finds the same number of years for the 'duces' (leaders) of the returned Jewish people, for which he refers to Breviarium temporum of Philo. ${ }^{99}$ This Breviarium is a forgery compiled by Gianni Nanni O.P. (1432-1502), better known as Annius of Viterbo, and published in 1498, together with other forgeries and with his own commentaries on the forged ancient texts: Commentaria fratri Johannis Annii Viterbiensis super opera diversorum auctorum de antiquitatibus loquentium (Commentaries on the works of various authors who spoke of antiquity), ${ }^{100}$ also known under the title of Antiquitatum variarum volumina XVII (Seven-

96 That is, the period from the return from Exile to Herodes 30 (see f. 17b3). So, excluding the 70 years of the Babylonian captivity (see above), the total should have been 519 (589-70), but there is a surplus of 45 years $(519+45=564)$, apparently because Mathatias is said to have reigned for fifty instead of five years (see above, before note-number 94).

${ }^{97}$ Mangenot 1912, col. 739 (587 BCE, fall of Jerusalem); Finegan 1998, p. 261 (586, fall of Zedekia); Scultetus (6th aetas: 586 years). For '589' see e.g. Grafton 1993, p. 277 (Scaliger, 1540-1609); Finegan 1998, p. 405 (James Ussher, 1581-1656); see also above, note 3. For 590 BCE, see e.g. Grafton 1993, p. 669/70 (fall of the temple); Finegan 1998, p. 190 (Hieronymus).

${ }^{98}$ Scultetus (1546, on the basis of 'Philo'): 191 years from Cyrus to Alexander the Great, and 164 years up to Judas Macchabaeus. See the table above: sub-totals of 191 and 164 (from Zorobabel to Iudas Hircanus, and from Iosephus primus to Ianneus Hircanus).

${ }^{99}$ Philo of Alexandria (20 BCE-50 CE). For the references, see col. 2 (Philo in breviario temporum) and col. 4 (Philo) of Scultetus (1546)'s "Ratio huius chronographiae". The actual title is slightly different: Breviarium de temporibus (cf. SchmidtBiggemann 2006, p. 108).

100 This edition can be accessed online: Biblioteca Virtual de Andalucía. 
teen books of various antiquities) and often called the Antiquities. ${ }^{101}$ Philo's Breviarium de temporibus constitutes 'liber' 14 of Antiquities, of which there were at least eighteen editions in Latin, from 1498 to 1612. Throughout the sixteenth and seventeenth centuries, however, writers expressed doubts about the Antiquities of Annius. ${ }^{102}$ Nevertheless, it "became one of the bestselling and most popular books of the sixteenth century" 103 and was used by many authors, such as Scultetus in his Chronographia, Roberto Bellarmino (1542-1621) in his Brevis chronologia ab orbe condito usque ad annum MDCXII (Short chronology from the beginning of the world up to the year 1612), ${ }^{104}$ and in the, to me yet unknown, source of Mayor's Gewu qiongli bianlan (1607). Another example is Martin Luther's Supputatio annorum mundi (Calculation of the years of the world; 1541): "Despite the fact that Annius' work was quickly revealed to be a forgery, it is clear from the ways in which Luther used Annius that he did not realize the work was fraudulent. Again, in this regard Luther was not very different from many other scholars and writers of the sixteenth century." ${ }^{105}$ Looking at the list of 'duces' for the period between the return from the Babylonian captivity and the start of the Maccabean kingdom, "we find such persons as Abner Semei, Eli Mattathias, Aser Maat, Artaxat Nagid, names that include elements found in the Lucan genealogy of Jesus. This fact may well have seemed to Luther to support the authenticity of 'Philo's' information." 106 As regards the period concerned in the genealogy of Jesus in the Gospel of Luke (3:2328), notice that, except for Zorobabel (Zerubbabel), the other persons

${ }^{101}$ For literature on Annius, see e.g. Whitford 2009, p. 45, note 7 (Roberto Weiss, Anthony Grafton, and Walter Stephens). See also Schmidt-Biggemann 2006.

102 Stephens 2004, pp. 204-206. Grafton blamed Athanasius Kircher for still "quoting the Annian Berosus as a genuine ancient text", in which way "he violated the normal rules of play for mid-seventeenth-century chronology" (2004, p. 176).

${ }^{103}$ Whitford 2009, p. 48.

104 The Brevis chronologia is part of his De scriptoribus ecclesiasticis liber unus (Cologne, 1613), which I consulted by way of "The digital library of the Catholic Reformation (Catholic Reformation texts. Religious Orders. Jesuit)". The only difference for the period concerned is the number of years for the first three "duces Iudaeorum" (Zorobabel, Resa, Ioannes): 32, 46, 40 (instead of 58, 66, 53).

105 Whitford 2009, p. 44. Due to Luther's use of 'Philo' (Annius), the 1920 edition of his Supputatio reproduces this text on pp. 19-21 (Philonis Breviarium de temporibus, without the extensive commentaries of Annius himself); see also p. 9 for bibliographical details on this Breviarium. Cf. Barr 1990, p. 58.

106 Barr 1990, p. 60/61. Notice also that Resa Mysciollam, the son of Zorobabel, reminds one of the latter's son Mesullam mentioned in 1 Chronicles 3:19, to which Annius refers in his commentary. Luther mentions him as "Resa Mesullam" (p. 108 of vol. 53 of the Weimar edition of his collected works, see preceding note). 
(Resa-Iannae) "are completely unknown from the OT [Old Testament] and the intertestamental literature."107

\section{Conclusion}

The manuscripts Gezhi aolüe and Renlei yuanliu (two versions), preserved in the Zikawei Library of Shanghai are the first texts to present such a detailed chronology. Not only do they mention the number of years of (six) world ages, ${ }^{108}$ but also the number of years for each patriarch, judge, king, etc. (a kind of counterpart to the list of the Chinese emperors before Christ in Martini's Sinicae historiae decas prima and Couplet's Tabula chronologica monarchiae Sinicae). A closer look at these tables shows that the manuscripts Gezhi aolüe (before 1723) and Renlei yuanliu (ca. 1700) did not merely copy Gewu qiongli bianlan (1607) in all respects, as some Minnan transliterations were replaced with Mandarin ones, numbers of years changed (e.g. 922 for 292), and even once a name was inserted (Cainan II). So the subject of biblecal chronology must have appealed to some converts, who found an unexpected source in an older text published by the Dominicans for the Chinese in Manila. It is likely that missionaries were not involved, because they would have replaced all Minnan transliterations, some of which are now presented as alternative names or pronunciations; probably they would also have skipped the names forged by Annius of Viterbo. Without further research, it remains unclear whether these manuscripts had any influence and whether they represent the interest of only a few people. What is striking is the virtual absence of Chinese dates (especially of the Flood), ${ }^{109}$ such as one sees in the Chinese writings of the Jesuits. ${ }^{110}$ At the same time,

${ }^{107}$ Brown 1999, p. 85, said of the two genealogies of Jesus, including that in Matthew 1:1-17, and for "the post-monarchial period covering some 575 years from the beginning of the Babylonian Exile to the birth of Jesus", excluding Shealtiel and Zerubbabel and, at the end, Joseph and Jesus.

${ }^{108}$ In the survey given below (Appendix 1) there are no examples of 'world ages' (except the four in Shengjing zhijie), but only of two 'periods': CreationFlood - Incarnation (sometimes: Creation-Moses - Incarnation).

109 Shengjing zhijie (see below, after note-number 116) gives Chinese dates for the births of Abraham, Moses and Christ, but not for the Flood (which took place in remote antiquity (shanggu 上古), see juan 2, f. 15b8; WXSB, vol. 4, p. 1664).

110 Zürcher 1995, p. 153: "The problems arising from the synchronization of Biblical and Chinese history are rarely mentioned in their Chinese writings, and even the remarkable coincidence of the supposed dates of the Deluge and the inundation under Yao is hardly given any attention. They obviously realized that here they were operating in a zone of danger full of ideological pitfalls." 
these manuscripts, by way of a stray book from the Philippines, rely again on a Vulgata chronology, like that in Shengjing zhijie 聖經直解 (Literal explanation of the Holy Scripture), which was reproduced in Daoxue jiazhuan 道學家傳 (Family tradition of the study of the Way; 1730s, final version 1865). ${ }^{111}$

\section{Appendix}

\section{Appendix 1: Survey of Chinese-Christian texts (seventeenth to eighteenth century): Vulgata or Septuagint chronology}

The missionaries in China apparently began by introducing a chronology that was close to that of the Vulgata. In his Tianzhu shilu 天主實錄 (Veritable Record of the Lord of Heaven) of 1584, Michele Ruggieri says that 2450 years elapsed from the Creation to Moses, and 1510 years from Moses to the Incarnation; in others words, the Incarnation took place 3960 years after the Creation. This number $(2450+1510)$ was left unchanged in the heavily revised reprint of ca. 1640 (Tianzhu shengiiao shilu 天主聖教實錄). ${ }^{112}$ As for the period from the Creation to Moses, Alphonso Vagnone in his Jiaoyao jielüe 教要解略 (Summary explanation of the 'Doctrina Christiana'; 1615), when introducing the Ten Commandments, has the same number of years (2450). ${ }^{113}$

In 1626, Xiong Mingyu 熊明遇 gives in his Ze cao 則草 (A Draft on Regularity) a slightly different number of years (4084) for the period Creation-Incarnation: viz. 1656 years until the Flood, and 2428 years until the Incarnation, followed by 1626 years until 'now', which gives a total of 5710 years for the age of the world in $1626 .{ }^{114}$

In the manuscript Zhimin xixue 治民西學 (The Western science of governing the people; 1630) Alfonso Vagnone gives the following list: 1650 years from Creation to Flood, then more than 300 years until Abraham,

\footnotetext{
${ }^{111}$ See below, note 144 .

112 Tianzhu shilu (1584), f. 25b-26a (in: CCT ARSI, vol. 1, pp. 52-53); Tianzhu shengiiao shilu (ca. 1640), f. 23b-24a (in: WXXB, vol. 2, pp. 810-811); even the number of years for the period from the Incarnation until 'now' was left unchanged: 1584 (f. $24 a 8 ;$ p. 811). The same applies to the number of years from the Creation until 'now', viz. more than 5550 years (f. 12a, p. 25; f. 9a, p. 781; in fact, 5544 years).

${ }^{113}$ CCT ARSI, vol. 1, p. 150 (juan shang, f. 13b).

${ }^{114}$ Xiong Mingyu, Ze cao, f. 4b (p. 120), cf. Xu Guangtai 2010, p. 192. See also Ze cao, f. 6 b (p. 121): at present the world is not yet 6000 years old 開䦕至今未滿六千 (cf. Xu Guangtai 2010, p. 195).
} 
more than 500 years until Moses, 440 years until David, more than 1100 years until the Incarnation, and 1630 years until now; ${ }^{115}$ so from Creation to Incarnation there have been more than 3990 years.

The Vulgata chronology was also used by Rui de Figueiredo, as we learn from the catechetical notes of Joseph Zhu Yupo 朱毓朴, collected in Shengjiao yuanliu 聖教源流 (The origin of the holy teaching; 1636): the Incarnation took place 4000 years after the Creation. ${ }^{116}$ This also applies to Manuel Dias' extensive explanations of the Gospel readings on Sundays and feastdays, Shengiing zhijie 聖經直解 (preface of May 1636, but completed probably in 1642). ${ }^{117}$ Dias gives the following periodization (with an implicit total of 4000 years): ${ }^{118}$

$\begin{array}{lrll}\text { 1) Creation-Flood } & 1056 & \text { years } & \\ \text { 2) Flood-Abraham } & 922 & \text { (夏王槐 17丁丑) } \\ \text { 3) Abraham-Moses } & 425 & \text { (商王太戊 39 王午) } \\ \text { 4) Moses-Incarnation } & 1597 & \text { (漢哀帝元壽 2 庚申) } \\ \text { Total } & 4000 & \end{array}$

The number of years (1056) for the first period is unusual, because tradition (Vulgata) unanimously gives 1656 years for this period. ${ }^{120}$ This difference of 600 years $(1656 / 1056)$ can hardly be a mistake or scribal error, and maybe one should agree with $\mathrm{Wu}$ Liwei that Dias possibly tried to adapt the Vulgata chronology to Chinese history by placing the Flood 2944

${ }^{115}$ CCT BnF, vol. 1, pp. 479-482 (juan shang, ff. 6-7). Thus from Creation to Moses there are more than 2450 years $(1650+300+500)$, cf. Jiaoyao jielüe just referred to; see also above, Gewu qiongli bianlan $(1656+292+505)$.

116 Shengjiao yuanliu, juan 1, f. 4a1 (CCT ARSI, vol. 3, p. 17).

11715 juan, reproduced in WXSB, vols. 4-6 (pp. 1553-3106); preface of 19 May 1636 崇禎丙子孟夏望日 (p. 2961); for 1642, see j. 9, f. 2a: 至今崇禎十五年相去一千六 百四十二年 (p. 2381).

118 Shengjing zhijie, juan 3, f. 2b (WXSB, vol. 4, p. 1730). These four periods are compared with the four periods of daytime in the parable told in Matthew 20.1-16 (the gospel reading for Sunday Septuagesima [in Chinese: the third Sunday before Lent], pp. 1727-1729, which Dias is explaining): early morning (卯時) - three hours later (已初)-midday (午正) - an hour before sunset (申初) - sunset (酉初). This parable was often used in explaining the successive 'world ages', cf. Schmidt 1955.

119 The 1597 years before the Incarnation refer to the birth of Moses, who was eighty when he received the Ten Commandments, 1517 years before the Incarnation (or: 商王祖乙七年王寅), see Shengjing zhijie, juan 1, f. 3a (p. 1559); cf. juan 9, f. 43b (p. 2464): Moses taught his people more than 3000 years before 'now' (1642).

${ }^{120}$ See above, note 3. See also, for example, Grafton 2006, p. 71. 
$(922+425+1597)$ years before the Incarnation. ${ }^{121}$ That Dias or a copyist did not make a mistake is confirmed later in the book (j. 9, f. 34a, where once again we find an implicit total of 4000 years): the circumcision of Isaac (eight days after his birth and 100 years after the birth of his father Abraham, see Genesis 21:4-5) is dated 2077 years after the Creation and 1923 years before the birth of Christ $(2077+1923=4000) ;{ }^{122}$ this fits with the dates Dias (j. 1, f. 2b) mentions for the birth of Abraham: $1978(1056+922)$ years after the Creation, and $2022(425+1597)$ years before the birth of Christ (see above). ${ }^{123}$

It seems that after 1637 missionaries indeed shifted to using the Septuagint chronology, which put the Incarnation about 5200 years after the Creation, ${ }^{124}$ e.g. 5199 years according the Martyrologium Romanum, so that, for example, around 1650 the world was believed to be some 6850 years old. The Septuagint chronology was already used, however, before 1637. Xu Dashou 許大受 in his Zuo pi 佐闢 (Aid in refuting [heterodoxy]; 1623) ridiculed the idea that the world could not be older than some 7000 years. ${ }^{125}$ However, Diego de Pantoja had already used the Septuagint chronology in his Renlei yuanshi 人類原始 (The origin of mankind; 1610), a text included in Pangzi yiquan 龐子遺詮 (Explanations left by Mr. Pang), and he gives the following periods: from the Creation (kaipi 開闢) to the Flood (hongshui 洪水) 2242 years, from the Flood to the Incarnation 2954 years, and from the Incarnation until now, Wanli gengxu 萬曆庚戌, 1610 years; so all together 6806 years from the Creation until $1610 .{ }^{126}$ In other words, from Creation to Incarnation there are 5196 years $(2242+2954)$.

${ }^{121} \mathrm{Wu}$ Liwei 2005 , p. 401; 2009, p. 297. Dias explicitly mentions the Flood, so it makes no sense to remark that ' 1056 ' is the year (after the Creation) when Noah was born, because the Flood took place 600 years after his birth (Genesis 7:6); cf. Renlei yuanshi (FJ 092R), f. 6a1 (CCT ZKW xubian vol. 26, p. 501).

122 Shengjing zhijie, juan 9, f. 34a (WXSB, vol. 5, p. 2445). Dias equates 1923 BC (or 2077 AM) with year 56 of the reign of Bujiang, eleventh king of the Xia dynasty (按 長曆為夏第十一王不降五十六年丙辰); cf. Daoxue jia zhuan 道學家傳 (1865), f. 23b (CCT ZKW, vol. 3, pp. 1071).

${ }^{123}$ Cf. Shengjing zhijie, juan 4, f. 59a3 (p. 1917): someone said to Jesus: "You are not yet fifty years old. How can you have seen Abraham?" (John 8:57); Dias comments: "Abraham had already died almost 2000 years before the time of our Lord's Incarnation" (Abraham died at age of 175, see Genesis 25:7).

124 See above, note 3. For 1637, see above (after note-number 20).

${ }^{125} \mathrm{Zuo}$ pi in: Xu Changzhi 徐昌治 (comp.), Shengchao poxie ji 聖朝破邪集 (Collection for destroying heterodoxies in our holy dynasty; 1640), juan 4, f. 24 (Xia Guiqi 1996, p. 213); cf. Gernet 1985, p. 212 (n. 90); Xu Guangtai 2010, p. 197.

${ }^{126}$ Renlei yuanshi in: Pangzi yiquan 龐子遺詮 (see above, note 18), juan 4, ff. 1-16a (CCT ARSI, vol. 2, pp. 221-251), f. 2b (p. 224); Xu Guangtai 2010, p. 190. In his 
A same author is also not always consistent. In his Wanwu zhenyuan 萬 物真原 (The true origin of all things; 1628) Giulio Aleni keeps to a Septuagint chronology: the world is not yet 7000 years old (see the end of note 146). In 1623, however, he writes in Zhifang waiji 職方外紀 (Record of countries outside of China) that, at that time, the world is 6000 years old, which probably is a rounded up number and not rounded down. ${ }^{127}$ In any event, in 1642 he keeps to a Vulgata chronology: there are 4000 years between Creation and Incarnation, as in his catechism in verses of four characters (Tianzhu shengjiao sizi jingwen 天主聖教四字經文; 1642): from the Creation to Moses there are more than 2450 years and then 1550 years until the Incarnation; at the same time he gives a 'Septuagint' date for the Flood, viz. 2245 years after the Creation. ${ }^{128}$

The Septuagint chronology is used in several texts dating after ca. 1637. According to João Monteiro's Tianxue lüeyi 天學略義 (Succint meaning of the celestial studies; 1642) the period Creation-Incarnation covers well over 5190 years. ${ }^{129}$ Also the catechist Zhu Zongyuan 朱宗元 (ca. 1616-1660) used the Septuagint chronology. According to his Zhengshi lüeshuo 拯世略說 (Succint exposition of saving the world) there are 6844 years from the Creation until 1644 (順治之甲申) (and thus until the Incarnation there are 5200 years: 6844 minus 1644) and the Flood took place some 2000 years after the Creation, that is some 4800 years ago, ${ }^{130}$ or in about 3200 BCE. ${ }^{131}$ In

undated Tianzhu shiyi xubian 天主實義續編 (Continuation of “True meaning of the Lord of Heaven") he leaves the question open (Vulgata or Septuagint chronology) and merely speaks of "several thousand years" (數千年); see f. $6 \mathrm{~b}$ (WXXB, vol. 1, p. 110); cf. Wu Liwei 2009, p. 284.

${ }_{127}$ Juan 1, f. 11a (TXCH, vol. 3, p. 1339), in the section on the country of Judea (ff. $10 b-14 b)$.

${ }^{128} \mathrm{ff} .6 \mathrm{~b}, 8 \mathrm{a}, 9 \mathrm{a}$ (CCT ARSI, vol. 2, pp. 320, 323, 325; the edition reproduced is a Jiangxi reprint of probably 1663, see pp. 300, 384). Not surprisingly, in a 1935 reprint of Sizi jingwen (I have not checked other reprints), the 'Septuagint' date for the Flood, viz. 2245 AM (usually 2242 [see above, note 3], which would mean 1755 $\mathrm{BCE}$ ), was changed into the 'Vulgata' date for the flood, viz. $1656 \mathrm{AM}$, in addition to slight changes in the other two dates: 2512 and 1492 (together 4004) instead of 2450 and 1550 years; see Ku Wei-ying 2008, pp. 328-329.

${ }^{129}$ f. $7 \mathrm{~b}$ (WXXB, vol. 2, p. 862).

130 f. 16 (section: Tiandi yuanshi 天地原始); Sachsenmaier 2001, p. 347 (BnF Chinois 7139). In his preface to Manoel Dias' Shijie zhiquan 十誡直詮 (Literal explanation of the Ten Commandments; 1642), Zhu places the Flood "more than 2000 years” (二千餘載) after the Creation, see BnF Chinois 7192, preface Zhu, f. 1b; see also Daoxue jia zhuan 道學家傳 (1865), CCT ZKW, vol. 3, p. 1031, column 1 (pp. 10301036 reproduce the text of Zhu's preface under the title of 'Jiaoyao' 教要). In the 
his undated Tianzhu shengjiao huoyi lun 天主聖教豁疑論 (Essay on clearing up doubts concerning the holy teaching of the Lord of Heaven; reprint of 1680) Zhu says that the world is not yet some 7000 years old (不過七千餘載) and that the Flood took place 2000 years after the Creation. ${ }^{132}$ In his Po mi lun 破迷論 (About destroying erroneous teachings), the content of which is very similar to his Tianzhu shengjiao huoyi lun $^{133}$ he was much more specific: from the Creation until now (章皇帝元年甲申之歲, i.e. 1644) there are 6842 years, and the Flood took place 1656 years after the Creation; ${ }^{134}$ thus, from Creation to Incarnation there are 5198 years (6842 minus 1644). Also Shang Huqing 尚祜卿 in his $B u R u$ wengao 補儒文告 (Statements concerning supplementing Confucianism; 1664) states that the world is not yet 7000 years old, and the comment in the upper margin (by the otherwise unknown Gan Lichuan 甘粒傳) specifies: 6862 years (minus 1664 leaves 5198 years for the period Creation-Incarnation). ${ }^{135}$ Tianxue chuan'gai 天學傳概 (Outline of the transmission of the celestial studies; 1664) of Li Zubai 李祖 白 implies the same number of years (5198): from the Creation to Moses (receiving the Ten Commandments at Mount Sinai), 3701 years, and from Moses to the Incarnation, 1497 years (together 5198). ${ }^{136}$ Ludovico Buglio's Zhujiao yaozhi 主教要旨 (The essentials of the Lord's teachings; preface:

main text of Shijie zhiquan Dias states that Moses received the Ten Commandments "more than 3000 years after the Creation" (juan shang, f. 6b). In an edition of 1814 (stored in the Biblioteca Apostolica Vaticana, Borgia cinese 348), however, 2000+ and $3000^{+}$were corrected into the more 'Vulgata-friendly' $1000^{+}$and $2000^{+}$(for 一千 餘載 see also Xu Zongze 1949, p. 181, or 2006, p. 138).

131 Cf. Zürcher 1995, p. 151: “Chu Tsung-yüan dates the Flood about 3200 BC apparently an unauthorized attempt to push it back as far as possible." It was not the date of the Creation that was a real problem for Chinese, but that of the Flood (see o.c. p. 149; cf. above, note 110). See also above (before note-number 121): within a Vulgate chronology Dias puts the Flood in 2944 BCE (that is 1056 AM).

${ }^{132}$ f. 6 (WXSB, vol. 2, pp. 541-542); cf. Wu Liwei 2009, p. 293/94. The reprint (ca. 1680) of Tianzhu shengjiao huoyi lun was revised by Stanislao Torrente (Qu Dude 雉 篤德, see f. 1a; p. 531), and possibly he made some changes to the text of the first edition, entitled Pomi lun 破迷論.

133 Sachsenmaier 2001, p. 44.

${ }^{134}$ Pomi lun, f. 6b/7a (CCT ZKW xubian, vol. 4, p. 386/87).

${ }^{135}$ Bu Ru wengao, juan 1, f. 24a/b (CCT ZKW xubian, vol. 3, p. 170/71), part of the section “Lun tiandi wanwu zhi yuan" 論天地萬物之原 (ff. 24-39; pp. 170-201). Cf. Mungello 2001, p. 49 (referring to the 'Leiden' transcript of $B u$ Ru wengao, see p. 186).

136 Tianxue chuan'gai, f. 1b/2a (WXXB, vol. 2, p. 1056/57); see also Wu Liwei 2009, p. 280 . 
1668, 9th month) also keeps to a Septuagint chronology: 6865 years have elapsed from the Creation to 1665 (Kangxi yisi 康熙乙巳), ${ }^{137}$ in other words: 5200 years from Creation to Incarnation. However, the time from Creation to Moses is in Buglio's text a thousand years shorter than in Li Zubai's Tianxue chuan'gai: Moses received the stone tablets with the Ten Commandments 2700 years after the Creation. ${ }^{138}$

The Septuagint chronology is also used in a short text composed by the Franciscan Carlo di Orazio da Castorano (1673-1755) that accompanies a map ( $t u$ 圖) with the genealogy of Jesus Christ, Wuzhu Yesu ji tianxia wanmin lidai zongpai tu 吾主耶穌及天下萬民歷代宗派圖 (Map of the genealogy of Our Lord Jesus and of all people on earth; 1704), ${ }^{139}$ a printed onefolio sheet of big format of which only one copy is known (preserved in the set Vat. Estr. Or. 55 of the Vatican Library): from the Creation to the Flood there were 2242 years, and from the Flood to the Incarnation 2957 years (and thus from Creation to Incarnation 5199 years). With the 1704 years up to Kangxi 42 癸未 (16 Febr. 1703 - 4 Febr. 1704) this gives a total of 6903 years $(5199+1704)$ for the age of the world at that time. Castorano concludes: this biblical chronology does not contradict Chinese history, which after all does not go back further than some 4500 years ${ }^{140}$ (in other words, Chinese history started after the Flood of 4661 years ago: $2957+1704=4661$ ). A final example of the use of the Septuagint chronology is the undated and anonymous Xingli canzheng 性理參證 (Detailed testimonies of natural philosophy), probably composed in 1816, which states that at present the world is more than 7000 years old. ${ }^{141}$

Although by now one may have formed the impression that since ca. 1637 the Vulgata chronology had disappeared in China, this is not really the

137 Zhujiao yaozhi, f. 9a3 (section 5: 天地人祖原始, ff. 8b4-11a1); consulted copy: BnF, Chinois 6917 (main text: 26 ff., 12 sections).

138 Zhujiao yaozhi, f. $21 \mathrm{a} 7$ (section 10: 十誡, ff. 21a1-21b6). In two texts using the Vulgata chronology this period is 2450 years (see above).

139 Taixi Sheng Fangjige huishi Kang Hezi shu 泰西聖方濟各會士康和子述 (in handwriting: Pr. Carolus Horatii à Castorano Regul. Observ. S. P. Fran.ci reverenter fecit circa Anno D.ni 1704 in civitate Lin zing ceu [臨清州] Provinciae Scian tung); tonghui Ye Zunxiao ding 同會葉尊孝訂 (in handwriting: R.mus P. Basilius a Glemona vic. Ap.licus visit et approbavit). Basilio Brollo (da Glemona) died on 16 Nov. 1704.

140 從 天主開天地到洪水二千二百四十二載從洪水到吾主耶穌降生二千九百五十 七載從吾主耶穌降生到現時康熙四十二癸未一千七百零四年總論六千九百零三年故不 用 天主聖教數年之法萬國荒唐繁多乃無據之言及若細察中華肇年之數不到四千五百 幾載之外 570).

41 七千餘年, ff. 75a, 88b (CCT ZKW, vol. 3，pp. 1529，1556); 七千年, f. $96 b$ (p. 
case (though not all are clear-cut). ${ }^{142}$ The section "Hongshui yi hou pu" 洪 水以後譜 (Register [of the generations] after the Flood) ${ }^{143}$ of Daoxue jiazhuan 道學家傳 (Family tradition of the study of the Way; 1865, date of the final version) $)^{144}$ gives the following scheme (ff. 19b-20a, pp. 1063-1064):

$\begin{array}{llc}\text { period } 1 \text { (卯時) Creation - Flood } & 1056 \text { years } \\ \text { period } 2 \text { (已初) } & \text { Flood - Abraham } & 922 \\ \text { period } 3 \text { (午正) Abraham - Moses } & 425 \\ \text { period } 4 \text { (申初) Moses - Incarnation } & 1597\end{array}$

That means a total of 4000 years for these four periods, which fits with the remark in the upper margin of this page (p. 1063, f. 19b) saying that up to Jiaqing 13 (1808) there are 5808 years, in other words 4000 years from Creation to Incarnation. This scheme is clearly derived from Dias' Shengjing zhijie (see above, after note-number 118), only that some reader corrected ' 1056 ' into ' 1656 ' (p. 1064), ${ }^{145}$ so that rather unusually the total becomes ' 4600 ' (the totals are not mentioned as such in the text).

There is another example of the use of a Vulgata chronology, this time towards 1790. Not surprisingly it is found in the context of a Chinese translation of the book of Genesis (Zaocheng jing 造成經, ff. 1-69a) based on the Vulgata which (the Clementina of edition of 1592) was the official Latin Bible of the Roman Catholic Church until 1979. This example also shows

142 See the undated (probably 1650s or 1660s) Bianji 讋祭 (A critique of sacrifice) of Francisco Varo O.P. (for which text see Menegon 2009, p. 112) quoted in Bianji canping 辡祭參評 (An impeachment of Bianji) there are more than 3900 years from Creation to Incarnation (CCT ARSI, vol. 10, p. 433). In his Budeyi bian 不得已辯 (Refutation of 'I cannot do otherwise' [by Yang Guangxian 楊光先]; 1665) Ludovico Buglio remarks that from emperor Yao 帝堯 to 1644 (Shunzhi 1) there are 4000 years (see f. 15b/16a; WX, p. 258/59). Acccording to Wu Liwei (2005, p. 402; id. 2009, p. 297), this indicates that Buglio used the Vulgata chronology. However, in his Zhujiao yaozhi 主教要旨 Buglio uses a Septuagint chronology (see above). Notice too that Budeyi bian, f. 16a3-7 (with the references to Nan Xuan 南軒 [1515-1596], Sima Qian 太史公, and Gangjian 綱鑑), contains virtually the same text as found in Giulio Aleni's Wanwu zhenyuan 萬物真原 of 1628 (f. 3a; CCT ZKW, vol. 1, p. 169; cf. Witek 1983 , p. 235, note 30), in which the world is supposed to be not yet 7000 years old (ff. $2 b, 3 b)$, in other words, a Septuagint chronology.

${ }^{143}$ CCT ZKW, vol. 3, pp. 1061-1065 (f. 18b3-20b), covering the period from the Flood until Moses.

${ }^{144}$ Daoxue jiazhuan actually dates to the Yongzheng period (1723-1735), but it was updated by copyists here and there; see Dudink 1996, p. 25 (sub 090R).

${ }^{145}$ Cf. Wu Liwei 2009, p. 301/302. 
that a Septuagint-derived chronology only could be maintained in China during the seventeenth and eighteenth centuries, because the Bible had not yet been translated at that time. After his manuscript and unpublished translation of Genesis, Louis de Poirot S.J. appended a short essay, entitled “Zaocheng jing zhi zonglun” 造成經之總論 (ff. 69b-71a), in which he gives a chronological survey of the book he just translated (without any reference, by the way, to a Septuagint chronology):

\begin{abstract}
Adam 亞當 (at the age of 130) begat Seth 瑟得, Seth (105) begat Enos 黑諾斯, Enos (90) begat Cainan 該南, Cainan (70) begat Malalehel 瑪拉肋耳, Malalehel (65) begat Iared 亞肋得, Iared (162) begat Enoch 黑諾克, Enoch (65) begat Mathusalam 瑪都撒冷, Mathusalam (187) begat Lamech 拉默克, Lamech (182) begat Noah 諾厄, and Noah was 600 years old at the time of the Flood. ${ }^{146}$ So the Flood occurred 1656 years after the Creation. After the Flood (1 year), 292 years elapsed until the birth of Abraham 亞巴 拉杭 in $1949 \mathrm{AM}^{147}$ father of Isaac 依撒 (born in $2049 \mathrm{AM}$ ), who died at the age of 180 [Gen. 35:28] in 2229 AM. His son, Jacob 亞各伯, died in Egypt in 2256 AM at the age of 147 [Gen. 47:28, cf. note 81], and Joseph 若瑟, Jacob's son, died in $2310 \mathrm{AM}$ at the age of 110 [Gen. 50:26, cf. note 82]. ${ }^{148}$
\end{abstract}

\footnotetext{
${ }^{146}$ Genesis 5 (verses 3, 6, 9, 12, 15, 18, 21, 25, 28) and Genesis 7:6 (age of Noah at the time of the Flood).

${ }^{147}$ Other people say "1948 years" (cf. note 77), but Louis de Poirot counts one year more in order to include the 'period' of the Flood itself.

${ }^{148}$ For the text, see CCT ZKW xubian, vol. 28. Compare the tables given above: First period (1656 yrs); Second period (292); Third period (up to Joseph's death: $100+60+130+71=361)$. Together $(1656+292+361)$ this is 2309 (plus 1 year for the Flood, is $2310 \mathrm{yrs}$ ). At the end of the translation of Deuteronomy (ch. 34, v. 7: Moses dies at the age of 120) Poirot mentions that the death of Moses occurred in 2493 AM, 836 years after the Flood $(2493-836=1657)$.
} 
Appendix 2: Carlo di Orazio da Castorano, Wuzhu Yesu ji tianxia wanmin lidai zongpai tu 吾主耶穌及天下萬民歷代宗派圖 (Map of the genealogy of Our Lord Jesus and of all people on earth; 1704) ${ }^{149}$

Deus, 亞當 (Adam)/赫褡 (Eva), 瑟德 (Seth), 赫諾穌 (Henos), 嘉宜南 (Cainan), 瑪辣勒赫爾 (Malaleel), 亞勒德 (Iared), 赫諾格 (Henoch), 瑪篤撒冷 (Mathusale), 辣默格 (Lamech), 諾赫 (Noe), 瑟默 (Sem), 亞爾法磉 (Arphaxad), 嘉宜南 (Cainan), ${ }^{150}$ 撒勒 (Sale), 耶帛爾 (Heber), 法勒熱 (Phaleg), 辣墺碔 (Ragau), 撒祿額 (Sarug)，納各爾 (Nachor), 達勒 (Thare), 亞巴郎 (Abraham), 義撒格 (Isaac), 亞各伯 (Iacob), 虞達 (Iudas), 法勒瑟 (Phares), 赫 瑟鑾 (Esron), 亞郎 (Aram), 亞彌納達伯 (Aminadab), 納亞算 (Naasson), 撒而 滿 (Salmon), 玻阿澤 (Booz), 遏帛德 (Obed), 耶瑟 (Iesse),

1) from David to Maria (Luke 3:24-31): ${ }^{151}$

達未德 (David), 納膽 (Nathan), 瑪達大 (Mathatha), 萌納 (Menna), 默爾 嘉 (Melea), 赫利亞敬 (Eliakim), 躍納 (Iona), 躍瑟 (Ioseph), 瑜達 (Iuda), 需默 睆 (Simeon), 勒味 (Levi), 瑪達德 (Mathat), 躍瑯 (Iorim), ${ }^{152}$ 赫利耶則爾 (Eliezer), 耶穌 (Iesu), 赫爾 (Her), 赫爾瑪膽 (Elmadam), 閣珊 (Cosan), 亞體 (Addi), 默爾吉 (Melchi), 聶理 (Neri), 撒辣弟赫爾 (Salathiel), 座樂巴帛爾 (Zorobabel), 勒撒 (Resa), 躍亞納 (Ioanna), 瑜達 (Iuda), 躍瑟 (Ioseph), 瑟默 議 (Semei), 瑪達弟亞 (Mathathia), 瑪達德 (Mahath), 納熱 (Nagge), 赫需 (Hesli), 納弘 (Nahum), 亞茉穌 (Amos), 瑪達弟亞 (Mathathia), 躍瑟 (Ioseph),

\footnotetext{
${ }^{149}$ See above, note 143. Notice that the genealogy of Christ or the Holy Family ('Shengjia puxi' 聖家譜系) in CCT ZKW, vol. 4, pp. 1855-1858, probably dates to the late nineteenth century. Cf. Dudink 1996, p. 34 (150R), note 84. In the following list I reproduce the Latin names as given in text of the genealogies (in Matthew 1 and Luke 3) in the Vulgata Clementina (1592, the standard Latin text of the Bible in the Catholic Church until 1979), see Novum Testamentum 1981.

${ }^{150}$ Cainan II, see above, note 75 .

${ }^{151}$ Not including Luke 3:23 ("Jesus ... the son of Joseph, son of Heli"), because here Joseph and Heli are replaced by Mary and Joachim. According to Annius of Viterbo (for whom see above, after note-number 99), Heli was another name for Joachim, and the text of Luke 3:23 was defective. In this way, the unsolvable problem of the two different genealogies of Jesus was solved: Matthew (1:1-17) gives the genealogy through Joseph, and Luke (3:23-38) through Mary. "His solution to the genealogia Salvatoris crux is still celebrated by the Church as his major achievement" (p. 132); see Stephens 1989, pp. 128-132 (part of chapter 3: "Annius of Viterbo, the Flood, and a new universal history”, pp. 98-138). Cf. Brown 1999, p. 589 (note 42).

${ }^{152}$ In the Chinese text the names of Ioram and Iorim must have been confused: Iorim 躍瑯 and Ioram 躍玲 (see next note).
} 
亞納 (Ianne), 默爾璣 (Melchi), 勒味 (Levi), 瑪達德 (Mathat), 躍亞敬 (Ioachim), 瑪利亞 (Maria), 耶穌 (Iesus).

2) from David to Joseph (Mathew 1:6-16):

達未德 (David), 撒犖滿 (Salomon), 落玻盖 (Roboam), 亞琵亞 (Abias), 亞 撒 (Asa), 躍撒法德 (Iosaphat), 躍玲 (Ioram), 153 阿濟亞 (Ozias), 躍亞膽 (Ioatham), 亞嘉澤 (Achaz), 赫澤璣亞 (Ezechias), 瑪納瑟 (Manasses), 亞滿 (Amon), 躍爾亞 (Iosias), 葉閣倪亞 (Iechonias), 撒辣帝赫爾 (Salathiel), 座樂 䔤帛爾 (Zorobabel), 亞琵於德 (Abiud), 赫利亞慶 (Eliacim), 亞座爾 (Azor), 撒鐸格 (Sadoc), 亞敬 (Achim), 赫利於德 (Eliud), 赫勒亞匝爾 (Eleazar), 瑪膽 (Mathan), 亞閣伯 (Iacob), 躍瑟 (Ioseph), 耶穌 (Iesus).

\section{References}

\section{Primary Sources}

Congshu jicheng chubian 叢書集成初編 (Collected collectanea, first series), Wang Yunwu 王雲五 (ed. in chief), Shangwu yinshuguan, 1935-1937; reprint Zhonghua shuju, 1983, 1996.

CCT ARSI: Yesuhui Luoma Dang'anguan Ming Qing tianzhujiao wenxian 耶穌 會羅馬檔案館明清天主教文獻 (Chinese Christian Texts from the Roman Archives of the Society of Jesus), edited by Nicolas Standaert and Ad Dudink, 12 vols., Taibei: Ricci Institute 利氏學社, 2002.

CCT BnF: Faguo guojia tushuguan Ming Qing tianzhujiao wenxian 法國國家圖 書館明清天主教文獻 (Chinese Christian Texts from the National Library of France), edited by Nicolas Standaert, Ad Dudink and Nathalie Monnet, 26 vols., Taibei: Ricci Institute, 2009.

CCT ZKW: Xujiahui cangshulou Ming Qing tianzhujiao wenxian 徐家匯藏書樓 明清天主教文獻 (Chinese Christian Texts from the Zikawei Library), edited by Nicolas Standaert, Ad Dudink, Huang Yilong 黃一農 and Chu Pingyi 祝平一, 5 vols., Taibei: Fujen Catholic University Press, 1996.

CCT ZKW xubian: Xujiahui cangshulou Ming Qing tianzhujiao wenxian xubian 徐家匯藏書樓明清天主教文獻續編 (Sequel to “Chinese Christian Texts from the Zikawei Library"), edited by Nicolas Standaert, Ad Dudink and Wang Renfang 王仁芳, 34 vols., Taibei: Ricci Institute, forthcoming.

${ }^{153}$ See preceding note. The genealogy of Jesus from Abraham on (Matthew 1.16) in Daoxue jiazhuan (f. 19a1-19b7) has: 藥郎 (f. 19a6; CCT ZKW, vol. 3, p. 1062). 
CZLS: Xu Guangqi etc. comp. 徐光啟等修輯, Chongzhen lishu 崇禎曆書 (Calendrical treaties of the Chongzhen reign), Shanghai: Guji chubanshe (Pan Nai 潘鼎 ed.), 2009.

Gaubil, Antoine, Traité de la chronologie chinoise, divisé en trois parties; composé par le Père Gaubil, missionnaire à la Chine, et publié pour servir de suite aux Mémoires concernant les Chinois, par M. Silvestre de Sacy, A Paris, chez Treuttel et Würtz libraires ... et à Strasbourg, même maison de commerce, M.DCCC.XIV.

Granada, Luis de, Obras del V.P.M. fray Luis de Granada; precede su vida escrita por Luis Muñoz, Madrid: Impr. de la Real Compañía, 1800; http://cdigital.dgb.uanl.mx/la/1080016378_C/1080016378_C.html.

Luther, Martin, Supputatio annorum mundi (Calculation of the years of world; 1541) in: D. Martin Luthers Werke: Kritische Gesamtausgabe, volume 53, Weimar: Hermann Böhlaus Nachfolger, 1920, pp. 1-184 (pp. 22-182).

Novum Testamentum Graece et Latine: Textus Graecus, cum apparatu criticoexegetico, Vulgata Clementina et Neovulgata (Gianfranco Nolli, ed.), Città del Vaticano, 1981.

Scultetus (Schultze), Alexander, Chronographia sive annales omnium fere regum, principum \& potentatuum, ab orbe condito ad hunc annum Domini M.D.XLV, Romae: H. de Cartulariis, 1546; http://daten.digitalesammlungen.de/ db/bsb00000947/images/.

Simon, Renée (ed.), Le P. Antoine Gaubil S.J., Correspondance de Pékin 17221759, Genève: Librairie Droz, 1970.

SKQSZB: Siku quanshu zhenben 四庫全書珍本 (Rare works from the Siku quanshu), Taibei : Shangwu yinshuguan, 12 集, 1934-35.

TXCH: Tianxue chuhan 天學初函 (First collection of celestial studies; 1626), Zhongguo shixue congshu 中國史學叢書 (Collectanea for Chinese Historical Studies) (Wu Xiangxiang 吳相湘 ed.), no. 23 (6 vol.), Taibei: Xuesheng shuju, 1965.

WX: Tianzhujiao dongchuan wenxian 天主教東傳文獻, Zhongguo shixue congshu 中國史學叢書 ( Wu Xiangxiang 吳相湘 ed.), no. 24 (1 vol.), Taibei: Xuesheng shuju, 1965. 
WXSB: Tianzhujiao dongchuan wenxian sanbian 天主教東傳文獻三編， Zhongguo shixue congshu 中國史學叢書 (Wu Xiangxiang 吳相湘 ed.), no. 21 (6 vols.), Taibei: Xuesheng shuju, 1972 (reprint 1985).

WXXB: Tianzhujiao dongchuan wenxian xubian 天主教東傳文獻續編， Zhongguo shixue congshu 中國史學叢書 (Wu Xiangxiang 吳相湘 ed.), no. 40 (3 vols.), Taibei: Xuesheng shuju, 1966.

WYG: Yingyin Wenyuange Siku quanshu 影印文淵閣四庫全書 (Photofacsimile reprint of the Wenyuan Pavillion copy of the Complete Books of the Four Treasuries), Taibei: Shangwu yinshuguan, 1983-1986.

Xiong Mingyu, Ze cao 則草 (A Draft on Regularity), 2 juan, pp. 92-118, 119130 of Xiong's Lüxuelou ji 綠雪樓集 in: Siku jinhui shu congkan 四庫禁燬 書叢刊 (Collectanea of the forbidden and destroyed books at the Occasion of the Complete [Imperial] Library in Four Branches of Literature), Beijing: Beijing chubanshe, 2000, vol. 185, pp. 83-520.

Xu Changzhi 徐昌治 (comp.), Shengchao poxie ji 聖朝破邪集 (Collection for destroying heterodoxies in our holy dynasty; 1640), preserved only through a reprint made in Japan, 1856; modern edition: Xia Guiqi 夏瑰 琦 (ed.), Shengchao poxie ji, Xianggang: Jiandao shenxue yuan 建道神學 院, 1996.

\section{Secondary Sources}

Barr, James, "Why the world was created in 4004 B.C.: Archbishop Ussher and biblical chronology", Bulletin of the John Rylands Library of Manchester 67 (1985), pp. 575-608.

"Luther and biblical chronology", Bulletin of the John Rylands University Library of Manchester 72 (1990), pp. 51-67.

Beckmann, Johannes, "Luis de Granada in chinesischer Übersetzung", Zeitschrift für Missions- und Religionswissenschaft 52 (1968), pp. 200-203.

Bernard, Henri, "L'Encyclopédie astronomique du Père Schall (Tch'ongtcheng li-chou 崇禎曆書, 1629, et Si-yang sin-fa li-chou 西洋新法曆書, 1645): La réforme du calendrier chinois sous l'influence de Clavius, de Galilée et de Kepler", Monumenta serica 3 (1938), pp. 35-77, 441-527.

Brown, Raymond E., The birth of the Messiah: A commentary on the infancy narratives in the gospels of Matthew and Luke (1977; new updated edition, 
1993), New Haven \& London: Yale University Press, 1999 (paperback edition).

Brunner, Paul, L'euchologe de la mission de Chine: Editio princeps 1628 et développements jusqu'à nos jours, Münster (Westfalen): Aschendorff, 1964.

Chan, Albert [Chen Lunxu 陳綸緒], Chinese books and documents in the Jesuit archives in Rome: A descriptive catalogue: Japonica-Sinica I-IV, Armonk \& London: M.E. Sharpe, 2002.

Chen Yuan 陈垣, Chen Yuan xueshu lunwen ji 陈垣学术论文集 (Collection of scholarly essays written by Chen Yuan [1880-1971]), vol. 1, Beijing: Zhonghua shuju, 1980.

Cordier, Henri, L'imprimerie sino-européenne en Chine, Paris: Leroux, 1901.

Dehergne, Joseph, Répertoire des jésuites de Chine de 1552 à 1800, Rome: Institutum Historicum, 1973.

"Catéchismes et catéchistes en Chine de 1584 à 1800", Monumenta serica, 47 (1999), pp. 397-478.

Dudink, Ad, "The Zikawei collection in the Jesuit Theologate Library at Fujen University (Taiwan): Background and draft catalogue", SinoWestern cultural relations journal 18 (1996), pp. 1-40.

ECCP: Arthur W. Hummel (ed.), Eminent Chinese of the Ch'ing Period (16441912), Washington: Library of Congress, 1943.

Fang Hao 方豪 (1910-1980), Fang Hao liushi ziding gao 方豪六十自定稿 (Fang Hao's writings up to the age of 60, final version made by himself), 2 vols., Taibei: Xuesheng shuju, 1969.

(1974a), “Laidun Hanxueyuan cang Lüsong Mingke hanji zhi yanjiu” 萊頓漢學院藏呂宋明刻漢籍之研究 (Study of a Chinese book printed in the Philippines during the Ming preserved in the Leiden Sinological Institute), in: id., Fang Hao liushi zhi liushisi zixuan daiding $g a o$ 方豪六十至六十四自選待定稿 (Fang Hao's writings from the age of 60 to 64 , selected by himself and in a preliminary version), Taibei: Xuesheng shuju, 1974, pp. 455-465.

(1974b), "Mingmo Manila huaqiao jiaohui zhi teshu yongyu yu xisu: $<$ Xinkan Liaoshi zhengiiao bianlan> yu <Doctrina Christiana en lengua China> ershu zhi zonghe yanjiu" 明末馬尼拉華僑教會之特殊用 語與習俗：《新刊僚氏正教便覽》與《Doctrina Christiana en lengua 
China 》二書之綜合研究 (The special terminology and customs of the church of overseas Chinese at Manila in the late Ming: A combined study of the two books Xinkan Liaoshi zhengjiao bianlan [see above, note 30] and Doctrina Christiana en lengua China), in: id., Fang Hao liushi zhi liushisi zixuan daiding gao 方豪六十至六十四自選待定稿 (Fang Hao's writings from the age of 60 to 64, selected by himself and in a preliminary version), Taibei: Xuesheng shuju, 1974, pp. 437-453.

Finegan, Jack, Handbook of biblical chronology: principles of time reckoning in the Ancient World and problems of chronology in the Bible, Peabody (Massachusetts): Hendrickson Publishers, 1998 (revised edition of the 1964 edition).

Gernet, Jacques (Janet Lloyd, trl.), China and the Christian impact: A conflict of cultures, New York: Cambridge University Press, 1985.

Grafton, Anthony, Joseph Scaliger: A study in the history of classical scholarship, vol. 2: Historical chronology, Oxford: Clarendon, 1993.

"Kircher's chronology", in Paula Findlen (ed.), Athanasius Kircher: The last man who knew everything, New York: Routledge, 2004, pp. 171-187.

Grafton, Anthony, "The chronology of the Flood", in: Martin Mulsow and Jan Assmann (eds.), Sintflut und Gedächtnis: Erinnern und Vergessen des Ursprungs, München: Wilhelm Fink, 2006, pp. 65-82.

Guo Mutian 郭慕天, “Mei Wending yu yesuhuishi zhi guanxi” 梅文鼎與耶 穌會士之關係 (Relations between Mei Wending and Jesuits), Shangzhi bianyiguan guankan 上智編譯館館刊 (Bulletin of the Institutum S. Thomae, Peiping) 3.6 (June 1948), pp. 233-235.

Han Qi 韓琦, “From Adam Schall von Bell to Jan Mikolaj Smogulecki: The introduction of European astrology in Late Ming and Early Qing China", Monumenta serica 59 (2011), pp. 485-490.

Jobes, Karen H., and Moisés Silva, Invitation to the Septuagint, Grand Rapids: Baker Academic, 2000.

Ku Wei-ying 古偉瀛 (Gu Weiying), “'Sizi jing wen', benweihua yu Taiwan tianzhujiao” 《四字經文》, 本位化與台灣天主教 (“The Four Characters Catechism', inculturation and Taiwanese catholicism), in Staf Vloeberghs (ed.), History of catechesis in China, Leuven: Ferdinand Verbiest Institute, 2008, pp. 317-337. 
Larsson, Gerhard, "The chronology of the Pentateuch: A comparison of the MT and LXX", Journal of biblical literature 102.3 (Sept. 1983), pp. 401-409. $[\mathrm{MT}=$ Masoretic or Hebrew text of the Old Testament; LXX = the Septuagint or Greek translation of it.]

Li Yan 李偘, “Mei Wending nianpu” 梅文鼎年譜 (Chronological biography of Mei Wending), in Li Yan, Zhong suan shi luncong 中算史論叢 (Collected essays on Chinese mathematics), vol. 3, 1955, pp. 544-576; reprinted in Li Yan Qian Baocong kexue shi quanji 李俨钱宝琮科学史全集 (Complete collection of writings on the history of science written by $\mathrm{Li}$ Yan and Qian Baocong), Shenyang: Liaoning jiaoyu chubanshe, 1998, vol. 7, pp. 515-545.

Mangenot, E., "Chronologie biblique", in E. Vigouroux (ed.), Dictionnaire de la Bible, tom. 2, part. 1 (C), Paris: Letouzey, 1912, cols. 718-740.

Menegon, Eugenio, Ancestors, virgins, and friars: Christianity as a local religion in late Imperial China, Cambridge (Mass.): Harvard University Press, 2009.

Mungello, David, The spirit and the flesh in Shandong, 1650-1785, Lanham: Rowman \& Littlefield, 2001.

Pelliot, Paul, review (with addenda/corrigenda) of Cordier 1901, Bulletin de l'École française d'Extrême-Orient (1903), pp. 108-116.

Pinot, Virgile, La Chine et la formation de l'esprit philosophique en France (16401740), Paris, 1932 (reprint Genève, 1971).

Sachsenmaier, Dominic, Die Aufname europäischer Inhalte in die chinesische Kultur durch Zhu Zongyuan (ca. 1616-1660), Nettetal: Steyler Verlag (Monumenta Serica monograph series; 47), 2001.

Schmidt, Roderich, "Aetates mundi: Die Weltalter als Gliederungsprinzip der Geschichte", Zeitschrift für Kirchengeschichte 67 (1955/56), pp. 288317.

Schmidt-Biggemann, Wilhelm, "Heilsgeschichtliche Inventionen: Annius von Viterbos 'Berosus' und die Geschichte der Sintflut", in Martin Mulsow and Jan Assmann (eds.), Sintflut und Gedüchtnis: Erinnern und Vergessen des Ursprungs, München: Wilhelm Fink, 2006, pp. 85-111.

Shi Yunli 石云里, “Nikolaus Smogulecki and Xue Fengzuo's True Principles of the Pacing of the Heavens: Its production, publication and reception", East Asian Science, Technology and Medicine 27 (2007), pp. 63-126. 
Sotheby's, The Library of Philip Robinson, Part II, The Chinese Collection, London, 1988.

Stephens, Walter E., Giants in those days: Folklore, ancient history, and nationalism, Lincoln and London: University of Nebraska Press, 1989.

"When Pope Noah ruled the Etruscans: Annius of Viterbo and his forged Antiquities", MLN [continues since 1962 Modern Language Notes], 119.1, Supplement [Studia Humanitatis: Essays in Honor of Salvatore Camporeale] (Jan. 2004), pp. S201-S223.

Tilly, Michael, Einführung in die Septuagint, Darmstadt: Wissenschaftliche Buchgesellschaft, 2005.

Tristram, Hildegard L. C., Sex Aetates Mundi. Die Weltzeitalter bei den Angelsachsen und den Iren: Untersuchungen und Texte, Heidelberg: Carl Winter, 1985.

Van der Loon, Piet, "The Manila incunabula and early Hokkien studies", Asia major 12 (1966), pp. 1-43; 13 (1967), pp. 95-186.

Van Kley, Edwin J., "Europe's 'discovery' of China and the writing of world history", American historical review 76 (1971), pp. 358-385.

Väth, Alfons, Johann Adam Schall von Bell S.J., Missionar in China, kaiserlicher Astronom und Ratgeber am Hofe von Peking 15921666: Ein Lebens- und Zeitbild, Köln: Bachem, 1933.

Vega Ramos, María José, “Computatio omnium temporum: La edad del mundo en la historiografía reformista", in Carmen Cordoñer and Juan Antonio González Iglesias (eds.), Antonio de Nebrija: Edad media y renacimiento, Salamanca: Universidad, 1994, pp. 97-106.

Von Collani, Claudia, "Johann Adam Schall von Bell: Weltbild und Weltchronologie in der Chinamission im 17. Jahrhundert", in Roman Malek (ed.), Western learning and Christianity in China: The contribution and impact of Johann Adam Schall von Bell, S.J. (1592-1666), Nettetal: Steyler Verlag, 1998, vol. 1, pp. 79-99.

Von den Brincken, Anna-Dorothee, Studien zur lateinischen Weltchronistik bis in das Zeitalter Ottos von Freising, Düsseldorf: Triltsch, 1957.

Historische Chronologie des Abendlandes: Kalenderreformen und Jahrtausendrechnungen. Eine Einführung, Stuttgart etc.: Kohlhammer, 2000.

Whitford, David M., The curse of Ham in the early modern era: The Bible and 
the justifications for slavery, Farnham: Ashgate, 2009.

Witek, John W, “Chinese chronology: A source of Sino-European widening horizons in the eighteenth century", in Actes du IIIe colloque international de sinologie, Chantilly 1980: Appréciation par l'Europe de la tradition chinoise à partir du XVIIe siècle, Paris, 1983, pp. 223-252.

Wu Liwei 吴莉苇, Dang Nuoya fangzhou zaoyu Fu Xi Shen Nong: Qimeng shidai Ouzhou de Zhongguo shanggu shi lunzheng 当诺亚方舟遭遇伏羲神 农：启蒙时代欧洲的中国上古史论争 (Running up against Fu Xi and Shen Nong on the ark of Noah: The controversy about China's remote antiquity during the Enlightenment in Europe), Beijing: Zhongguo renmin daxue chubanshe, 2005.

"Ming Qing shiren dui shengjing niandai tixi de jieshou yu lijie: Yi Li Zubai Tianxue chuan'gai wei ge an" 明清士人对圣经年代体系的接受 与理解: 以李祖白 《天学传概》为个案 (Literati's accepting and understanding Bible chronology during Ming and Qing dynasties: A case study of Li Zubai's Tianxue chuan'gai), Zhonghua wenshi luncong 中 华文史论丛 (Journal of Chinese literature and history), 2009:1, pp. 277310.

Wylie, A. [Alexander], Notes on Chinese literature: with introductory remarks on the progressive advancement of the art; and a list of translations from the Chinese into various European languages, Shanghai: Presbyterian mission press, 1867. Second edition reprinted from the original edition with a new introduction by Dr. Howard S. Levy, New York: Paragon Book Reprint Corp., 1964.

Xu Guangtai 徐光台, “Donglin renshi Xiong Mingyu fouding yesuhuishi zhuzhang Zhongguoren wei Nuoya houyi" 東林人士熊明遇否定耶穌 會士主張中國人為諾亞後裔 (Donglinist Xiong Mingyu negated Jesuits' view that the Chinese are the offspring of Noah), Sino-Christian studies 9 (2010), pp. 173-205.

Xu Zongze 徐宗澤, Ming Qing jian yesuhuishi yizhu tiyao 明清間耶穌會士譯 著提要 (Summary descriptions of the translations and writings of Jesuits during the Ming and Qing), Shanghai: Zhonghua shuju, 1949 (Taibei: Zhonghua shuju, 1958; Beijing: Zhonghua shuju, 1989; Shanghai: Shanghai shudian, 2006; Shanghai: Shanghai shiji /repr. 2010).

Zhang Xiping 張西平, “Feilübin zaoqi de Zhongwen keben zai yanjiu: yi Xinbian gewu qiongli bianlan wei zhongxin" 菲律宾早期的中文刻本再 
研究: 以《新编格物穷理便览》为中心 (Further study of the earliest Chinese books printed in the Philippines: Focusing on Xinbian gewu qiongli bianlan), Nanyang wenti yanjiu 南洋问题研究 (Southeast Asian Affairs) 143 (2010, no. 3), pp. 73-80.

Zhang Xiumin 張秀民 (revised and extended by Han Qi 韓琦), Zhongguo yinshua shi 中国印刷史 (History of printing in China), Hangzhou: Zhejiang guji chubanshe, 2006.

Zürcher, Erik, "In the beginning: 17th century Chinese reactions to Christian creationism", in Huang Chun-chieh and Erik Zürcher (eds.), Time and space in Chinese culture, Leiden: Brill, 1995, pp. 132-166.

The Buddhist conquest of China: The spread and adaptation of Buddhism in early medieval China (Leiden: Brill, 1959; reprint 2007). 